\title{
Grylloblattidan insects from Sperbersbach and Cabarz (Germany), two new early Permian and insect-rich localities
}

\author{
Yingying Cui, ${ }^{1 *}$ Stephan Brauner, ${ }^{2}$ Joerg W. Schneider, ${ }^{3,4}$ and Olivier Béthoux ${ }^{5}$ ( \\ ${ }^{1}$ College of Life Sciences, South China Normal University, Guangzhou, China <cuiying19860105@gmail.com> \\ ${ }^{2}$ Geopark Thüringen Inselsberg—Drei Gleichen, Friedrichroda, Germany <miocidaris@web.de> \\ ${ }^{3}$ Technical University Bergakademie Freiberg, Freiberg, Germany <Joerg.Schneider@geo.tu-freiberg.de> \\ ${ }^{4}$ Kazan Federal University, Kazan, Russian Federation \\ ${ }^{5}$ CR2P (Centre de Recherche en Paléontologie-Paris), MNHN_CNRS—Sorbonne Université, Paris, France <obethoux@mnhn.fr>
}

\begin{abstract}
New fossil insect specimens from two new localities in Germany, namely Sperbersbach and Cabarz (Goldlauter Formation; early Permian), belonging to the Grylloblattida, are described. Abundant material is assigned to Pictoborella clara n. gen. n. sp., regarded as closely related to Pictoborella germanica (Prokop et al., 2012) n. comb., from the Saar-Nahe Basin (Germany; early Permian). Liomopterum fuscatum n. sp., represented by fewer specimens, is delimited based on previously published and new data on various Liomopterum spp. Two other Liomopteridae, Uralioma thuringiensis n. sp. and Liomopterites sperbersbachensis n. sp., each known from a single forewing, are also described. Finally, Cabarzopterum magnificus n. gen. n. sp., with unclear familial affinities, is described based on three forewings. The assemblages of grylloblattidan insects at Sperbersbach and Cabarz are generally similar, with differences probably related to different depositional environments and local paleoclimatic conditions.
\end{abstract}

UUID: http://zoobank.org/25ae125c-6a17-415f-8cf0-4c0507e4f89d

\section{Introduction}

The so-called 'grylloblattidan insects' have a fossil record ranging from the late Carboniferous (Pennsylvanian) to the Cretaceous (Storozhenko, 1998). Whether they represent winged stem-relatives of the now depauperate and wingless group of icecrawlers (Grylloblattodea; Rasnitsyn, 1976) remains an open question (Wipfler et al., 2014). There is a growing body of evidence that stem representatives of the Grylloblattodea, and/or of the larger taxon Xenonomia (also including the wingless gladiators, Mantophasmatodea; Wipfler et al., 2019), occurred as early as the late Paleozoic (Evangelista et al., 2019; Montagna et al., 2019), which is consistent with the proposal that the winged fossil species and the wingless extant ones are related. If this is the case, Grylloblattodea had its heyday during the Permian, when it represented an important fraction of the entomofauna (Storozhenko, 2002; Beckemeyer and Hall, 2007; Aristov et al., 2013). Indeed, recent excavations conducted at Cabarz and Sperbersbach (Germany) revealed that these insects abound in these two new, insect-rich early Permian localities. Herein, we describe newly collected material and provide new documentation of specimens previously recovered from various early Permian localities, including some from Germany, relevant for the systematic treatment.

*Corresponding author.

\section{Materials and methods}

Documentation of fossil material.-Photographs of material from Cabarz and Sperbersbach, and of material housed at the Muséum National d'Histoire Naturelle (MNHN), were taken using a Canon EOS 5D Mark III camera equipped with a Canon MP-E $65 \mathrm{~mm}$ macrolens with a polarizing filter. Photographs of material housed at the Museum of Comparative Zoology (MCZ), were taken using a Canon EOS 550D camera coupled with a Canon MP-E $65 \mathrm{~mm}$ macrolens. Photographs of material housed at the Institute of Geosciences, Paleontology (IGPB), were taken using a Nikon D3X camera equipped with a $60 \mathrm{~mm}$ macrolens (specific type not documented).

All photographs were optimized using Adobe Photoshop CS6 (Adobe Systems, San Jose, California, USA). This included a readjustment of fragments in cases when a specimen had been broken. Composites were further generated using photographs taken under both dry conditions and with a thin film of ethanol. If using one side only, these are referred to as 'eth.-dry' composites. To obtain optimal documentation of coloration patterns, more elaborate composites where generated using: (1) photographs of the best-preserved side under both dry and ethanol conditions; and (2) a photograph of the other side under ethanol condition. These are referred to as 'eth.-eth.-dry' composites. Whenever relevant, the light-mirror effect (i.e., optical effect rendering a negative imprint as positive) was applied.

Three reflectance transformation imaging (RTI) files were generated to provide documentation of morphological features 
best appreciated under varied light orientations. For each RTI file, 42 photographs were taken using a $\sim 30 \mathrm{~cm}$ diameter, automated light dome driving a Canon EOS 5D Mark III digital camera coupled to a Canon MP-E $65 \mathrm{~mm}$ macrolens. Original photographs were optimized using Adobe Photoshop CS6 prior to RTI-processing, itself achieved using the RTIbuilder software (Cultural Heritage Imaging). See the online Dryad dataset for the generated RTI files. Items composing Figures 4.6 and 10.3 were extracted using the 'specular enhancement' mode. Items composing Figure 10.2 and 10.4 were extracted using the 'normals visualisation' mode, which assigns a color code to each pixel according to the orientation of the vector perpendicular to the tangent plane of the object at the corresponding point. These extracts were optimized for contrast.

All drawings were finalized using Adobe Illustrator CS6 (Adobe Systems, San Jose, California, USA). For material from Cabarz and Sperbersbach, as well as MNHN material, handdrafted drawings were prepared with the aid of a Zeiss SteREO Discovery V8 Stereomicroscope equipped with a pair of W-PL 10x/23 eye pieces, a Plan Apo S 1.x FWD objective, and a drawing tube (Jena, Germany). Final drawings were prepared using a multilayered file, including the handmade draft drawing and photographs. For MCZ material, handmade draft drawings were prepared with a dissecting microscope equipped with a drawing tube (specific characteristics not documented). For IGPB material, a final drawing was prepared using photographs only.

Terminology.-We follow wing venation terminology widely accepted for grylloblattidan insects (e.g., by Storozhenko, 1998) except for $M_{5}$, which we regard as a strengthened crossvein. Abbreviations include: $\mathrm{AA}=$ anterior Analis; $\mathrm{AA} 1=$ first branch of $\mathrm{AA} ; \mathrm{Cu}=$ Cubitus; $\mathrm{CuA}=$ anterior Cubitus; $\mathrm{CuA} 1=$ anterior branch of $\mathrm{CuA} ; \mathrm{CuA} 2=$ posterior branch of $\mathrm{CuA} ; \mathrm{CuP}=$ posterior Cubitus; $\mathrm{M}=$ Media; $\mathrm{MA}=$ anterior Media; $\mathrm{MP}=$ posterior Media; $\mathrm{R}=$ Radius; $\mathrm{RA}=$ anterior Radius; RP= posterior Radius; ScP, posterior Subcosta. For terminology of hindwing areas, we follow Brannoch et al. (2017).

Locality information.-New specimens described/mentioned below were collected from two localities in the Thuringian Forest Mountains, eastern Germany, both belonging to the Lower Rotliegend Lower Goldlauter Formation, early Asselian (early Permian) in age (Schneider et al., 2020). Cabarz is an active quarry at the Inselsberg Mountain in the vicinity of the Cabarz urban district of the town of Tabarz $\left(50^{\circ} 51^{\prime} 37.26^{\prime \prime} \mathrm{N}\right.$, $\left.10^{\circ} 29^{\prime} 37.26^{\prime \prime} \mathrm{E}\right)$. Specimens were collected from the lake horizon on quarry floor $2 \mathrm{a}$. Sperbersbach is an excavation site located near the Schmücke settlement in the vicinity of Gehlberg village $\left(50^{\circ} 39^{\prime} 11.55^{\prime \prime} \mathrm{N}, 10^{\circ} 46^{\prime} 45.0^{\prime \prime} \mathrm{E}\right)$. Specimens were collected from the Lower Acanthodes Lake Horizon. The origin of new specimens considered in the study is summarized in Table 1.

Both localities belong to the Sysciophlebia balteata - Spiloblattina homigtalensis insect zone and the Apateon flagrifer flagrifer - Branchierpeton reinholdi-Melanerpeton eisfeldi amphibian zone. Each of these is correlated on the basis of insect co-occurrences with marine zone-species as well by radioisotopic ages with the early Asselian (Schneider et al., 2020) of the Global Standard Chronostratigraphic Scale (Cohen et al., 2020).
Table 1. Collecting information of specimens from Sperbersbach and Cabarz (Germany).

\begin{tabular}{|c|c|c|c|}
\hline Species & $\begin{array}{c}\text { Specimen } \\
\text { (NHMS no.) }\end{array}$ & Locality & Figure \\
\hline \multirow[t]{16}{*}{ Pictoborella clara n. gen. n. sp. } & Am 3210 & Sperbersbach & \\
\hline & Am 3214 & & $4.1,4.2$ \\
\hline & Am 3237 & & 1.2 \\
\hline & Am 3244 & & 1.4 \\
\hline & Am 3246 & & 1.3 \\
\hline & Am 3264 & & \\
\hline & Am 4430 & & \\
\hline & $\mathrm{Am} 7058$ & & 1.1 \\
\hline & WP 6210 & & \\
\hline & WP 6331 & & \\
\hline & WP 4690 & Cabarz & 3.1 \\
\hline & WP 5124 & & 3.2 \\
\hline & WP 5759 & & $4.5,4.6$ \\
\hline & WP 5893 & & $4.3,4.4$ \\
\hline & WP 6092 & & 2 \\
\hline & WP 11308 & & \\
\hline \multirow[t]{10}{*}{ Liomopterum fuscatum n. sp. } & Am 3730 & Sperbersbach & 8.3 \\
\hline & WP 6199 & & 8.2 \\
\hline & WP 6386 & & 8.1 \\
\hline & WP 6440 & & \\
\hline & WP 6641 & & \\
\hline & WP 7961 & & 9.1 \\
\hline & WP 7964 & & \\
\hline & WP 5984 & Cabarz & 9.2 \\
\hline & WP 6155 & & \\
\hline & WP 7834 & & 10 \\
\hline Uralioma thuringiensis $\mathrm{n} . \mathrm{sp}$. & WP 5850 & Cabarz & 13 \\
\hline Liomopterites sperbersbachensis $\mathrm{n}$. sp. & Am 3212 & Sperbersbach & 14 \\
\hline \multirow{3}{*}{ Cabarzopterum magnificus $\mathrm{n}$. gen. n. sp. } & WP 5127 & Cabarz & 15.1 \\
\hline & WP 5696 & & 15.2 \\
\hline & WP 7831 & & 15.3 \\
\hline
\end{tabular}

Repositories and institutional abbreviations.-Specimens examined in this study are deposited in the following institutions: NHMS (WP or Am) $=$ Naturhistorisches Museum Schloss Bertholdsburg Schleusingen, Germany; MNHN= Muséum National d'Histoire Naturelle, Paris; MCZ = Museum of Comparative Zoology, Cambridge, Massachusetts, USA; IGPB = Institute of Geosciences, Paleontology, Bonn, Germany.

\section{Systematic paleontology}

Class Insecta Linnaeus, 1758

Order Grylloblattida Walker, 1914

Remarks. - The systematics of fossil grylloblattidan insects is not fully satisfactory, a consequence of the combination of a paucity of available characters, incompletely documented intraspecific variability, and homoplasy. The aim of this contribution is not to address this systematic impediment. Nevertheless, we discuss some uncertainties where necessary.

\section{Family Lemmatophoridae Sellards, 1909}

Remarks.-The genus Oborella Kukalová, 1964, to which the genus Pictoborella n. gen. is closely related, has been alternatively assigned to Lemmatophoridae (Carpenter, 1992) or to Euryptilonidae Martynov, 1940 (Storozhenko, 1998). The latter taxonomic concept has also been considered part of the former (Prokop et al., 2012). Except for very distinctive genera, differences between the two taxa can prove meager. A simple 
MA is a feature common of 'typical Lemmatophoridae' forewings; several genera of Euryptilonidae, including the type genus, have this vein branched (Storozhenko, 1998). The former condition is present in species herein assigned to Pictoborella n. gen., therefore, we tentatively assign this genus to Lemmatophoridae.

\section{Genus Pictoborella new genus}

Type species.-Pictoborella clara n. gen. n. sp., from Cabarz and Sperbersbach, Germany; early Permian.

Other species.—Pictoborella germanica (Prokop et al., 2012) n. comb., from Saar-Nahe Basin, Germany; early Permian.

Diagnosis.-Forewing: area between anterior wing margin and $\mathrm{ScP}$ distinctly broader than that between $\mathrm{ScP}$ and $\mathrm{RA}$; $\mathrm{ScP}$ veinlets well developed, ranging from 13 to at least 15 , usually simple, connected by one or two crossveins more or less aligned; RA slightly posteriorly bent distal to ending of $\mathrm{ScP}$; RP usually with two branches (rarely three); occurrence of $\mathrm{M}+\mathrm{CuA} / \mathrm{CuA} 1$ fusion; MA simple (rarely with two branches); MP with two branches (rarely three); CuA1 with two branches (rarely three), with first fork at midlength or slightly later; pigmented patches surrounding crossveins and $\mathrm{ScP}$ veinlets, and occurring inside vein forks; occurrence of rounded patch in anterodistal area, distal to end of ScP, more strongly colored.

Hindwing: essentially as forewing, except for occurrence of developed plicatum, narrower area between anterior wing margin and $\mathrm{ScP}$, and earliest position of RA/RP split; relation between $\mathrm{M}$ and $\mathrm{Cu}$ unknown.

Occurrence.-Cabarz, Sperbersbach, and Saar-Nahe Basin, Germany; early Permian.

Etymology.-Derived from the pre-existing genus name Oborella, to which was added a prefix derived from pictus: L., decorated or painted; referring to the coloration pattern present in both the fore- and hindwing.

Remarks. - The new genus is presumably closely related to the genus Oborella, with which it shares a long $\mathrm{M}+\mathrm{CuA} / \mathrm{CuA} 1$ fusion in the forewing. Our data on material herein assigned to Pictoborella clara n. gen. n. sp. (Figs. 1-4) and new data on the type material of Pictoborella germanica (Fig. 5), itself previously assigned to the genus Oborella, show that both possess a very similar coloration pattern. The occurrence of a patch darker than other colored areas, very conspicuous in material of Pictoborella clara n. gen. n. sp., is not evident in the holotype of Pictoborella germanica (Fig. 5.1), but it might be due to the fossilization of this material, which might have preserved pigmentation but not its shades. The hindwing of the paratype (Fig. 5.2) clearly displays a darker anterodistal patch.

Besides Pictoborella germanica, no other species previously assigned to Oborella (see Prokop et al., 2012) displays the coloration pattern diagnostic of Pictoborella n. gen. Coloration pattern, however, might not be adequately preserved in material from Obora (Czech Republic; early Permian), as indicated by the lack of coloration pattern in Spliloblattinidae Handlirsch, 1906 known from this locality, although it is usual that they display some (Schneider, 1982; Schneider and Werneburg, 1993). Besides coloration, O. inexpectata Kukalová, 1964, O. rotunda (Kukalová, 1964), and O. oviformis (Kukalová, 1964) each possess a branched MA, although this vein is very generally simple in species of Pictoborella n. gen. Additionally, whereas RP is very generally two-branched in species of Pictoborella n. gen., it has more than two branches in most Oborella species, except for $O$. rotunda and unknown in $O$. falsa (Kukalová, 1964). Oborella falsa is unusual in lacking the $\mathrm{M}+\mathrm{CuA} / \mathrm{CuA} 1$ fusion (although the veins closely approximate), present in all species of Pictoborella n. gen.

Oborella brauckmanni Prokop et al., 2012 is known from very incomplete material (Fig. 6). It lacks the coloration pattern typical of species of Pictoborella $\mathrm{n}$. gen. but shares with them, in the forewing, a simple MA and a two-branched RP. However, $\mathrm{CuA} 1$ is simple in the forewing of this species, unlike in species of Pictoborella n. gen. and other Oborella.

Finally, Oborella monsjovisensis Poschmann and Nel, 2020 not only lacks the coloration pattern diagnostic of the new genus, but also the long $\mathrm{M}+\mathrm{CuA} / \mathrm{CuA} 1$ fusion occurring in all species of Pictoborella n. gen. and almost all known Oborella species (with the exception of $O$. falsa). It also has a branched MA, in which it further differs from species of Pictoborella n. gen. Oborella monsjovisensis will be further discussed below, as a putative member of Liomopteridae.

A coloration pattern similar to that of species of Pictoborella n. gen. was reported in Maculopterum maculatum Kukalová, 1964 from Obora (see original description), known from the basal two-thirds of a single forewing. In this species, however, the area between the anterior wing margin and $\mathrm{ScP}$ is much narrower than in species of Pictoborella n. gen.

\section{Pictoborella clara new species}

Figures 1-4

Holotype.-NHMS-Am 7058, from Sperbersbach, Germany; early Permian (Fig. 1.1).

Diagnosis. - In both fore- and hindwing, apex with alternating pigmented and unpigmented areas (as opposed to 'apex uniformly pigmented,' as in Pictoborella germanica).

Occurrence.-Cabarz and Sperbersbach, Goldlauter Formation (Germany; early Permian).

Description.-Forewing: $11.7-13.4 \mathrm{~mm} \quad$ long, $\quad 4.0-4.8 \mathrm{~mm}$ wide; $\mathrm{ScP}$ reaching anterior wing margin distal to second third of wing length; veinlets between anterior wing margin and ScP well developed, mostly simple, connected by one or two crossveins, more or less aligned; RA/RP split opposite of slightly distal to first third of wing length; RA with veinlets reaching anterior wing margin, with more or less pronounced posterior bending in its distal part; first fork of RP near second third of wing length; RP with two branches (rarely three); area between RA and RP at its broadest opposite first fork of RP; base of $\mathrm{M}$ very weak; $\mathrm{M}$ forked earlier than $\mathrm{R}$; MA simple 

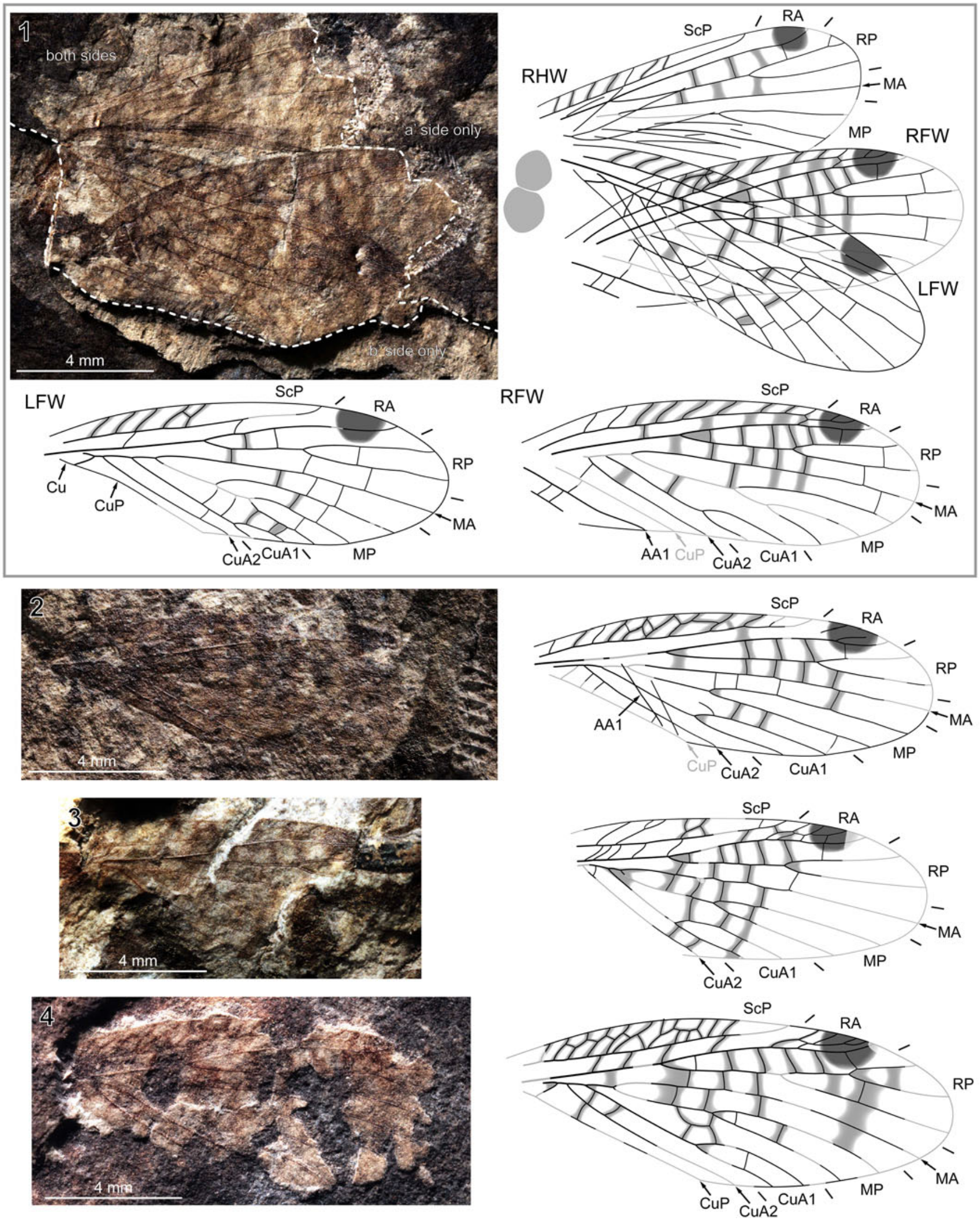
Figure 1. Pictoborella clara n. gen. n. sp.: (1) NHMS-Am 7058, holotype, photograph (positive imprint, eth.-eth.-dry composite; dotted lines indicate edges of imprints) and reconstructions of all wings in resting position and forewings separated; (2) NHMS-Am 3237, right forewing, photograph (negative imprint, lightmirrored, flipped horizontally, eth.-eth.-dry composite) and reconstruction; (3) NHMS-Am 3246, left forewing, photograph (positive imprint, flipped horizontally, eth.-eth.-dry composite) and reconstruction; (4) NHMS-Am 3244, right forewing, photograph (positive imprint, eth.-eth.-dry composite) and reconstruction. AA1 = anterior branch of the anterior Analis; $\mathrm{Cu}=$ Cubitus; $\mathrm{CuA} 1=$ anterior branch of the anterior Cubitus; $\mathrm{CuA} 2=$ posterior branch of the anterior $\mathrm{Cubitus} ; \mathrm{CuP}=$ posterior Cubitus; LFW = left forewing; $\mathrm{MA}=$ anterior Media; $\mathrm{MP}=$ posterior Media; $\mathrm{RA}=$ anterior Radius; $\mathrm{RFW}$ = right forewing; $\mathrm{RHW}=$ right hindwing; $\mathrm{RP}=$ posterior Radius; $\mathrm{ScP}=$ posterior Subcosta.

(with rare exception); MP forked later than $\mathrm{R}$ and earlier than $\mathrm{RP}$, with two branches (rarely three); $\mathrm{CuA} / \mathrm{CuP}$ split located very basally; $\mathrm{CuA}$, and then $\mathrm{CuA} 1$, fused with $\mathrm{M} ; \mathrm{CuA} 1$ with two branches (rarely three), with its (first) fork near its midlength, earlier than that of MP; CuA2 simple; CuP weak, straight; AA1 strong, simple; crossveins mostly scalariform, occasionally reticulated (in particular in area between MP and
$\mathrm{CuA} 1$ ), evenly distributed, most often delimiting cells longer than wide; pigmented patches surrounding crossveins and ScP veinlets, and occurring inside vein forks; in anterodistal area, distal to end of ScP, occurrence of strongly pigmented anteroapical patch; fine setae on membrane.

Hindwing: $\sim 10.4 \mathrm{~mm}$ long (derived from specimen NHMS-WP 6092 only); essentially as forewing, except for
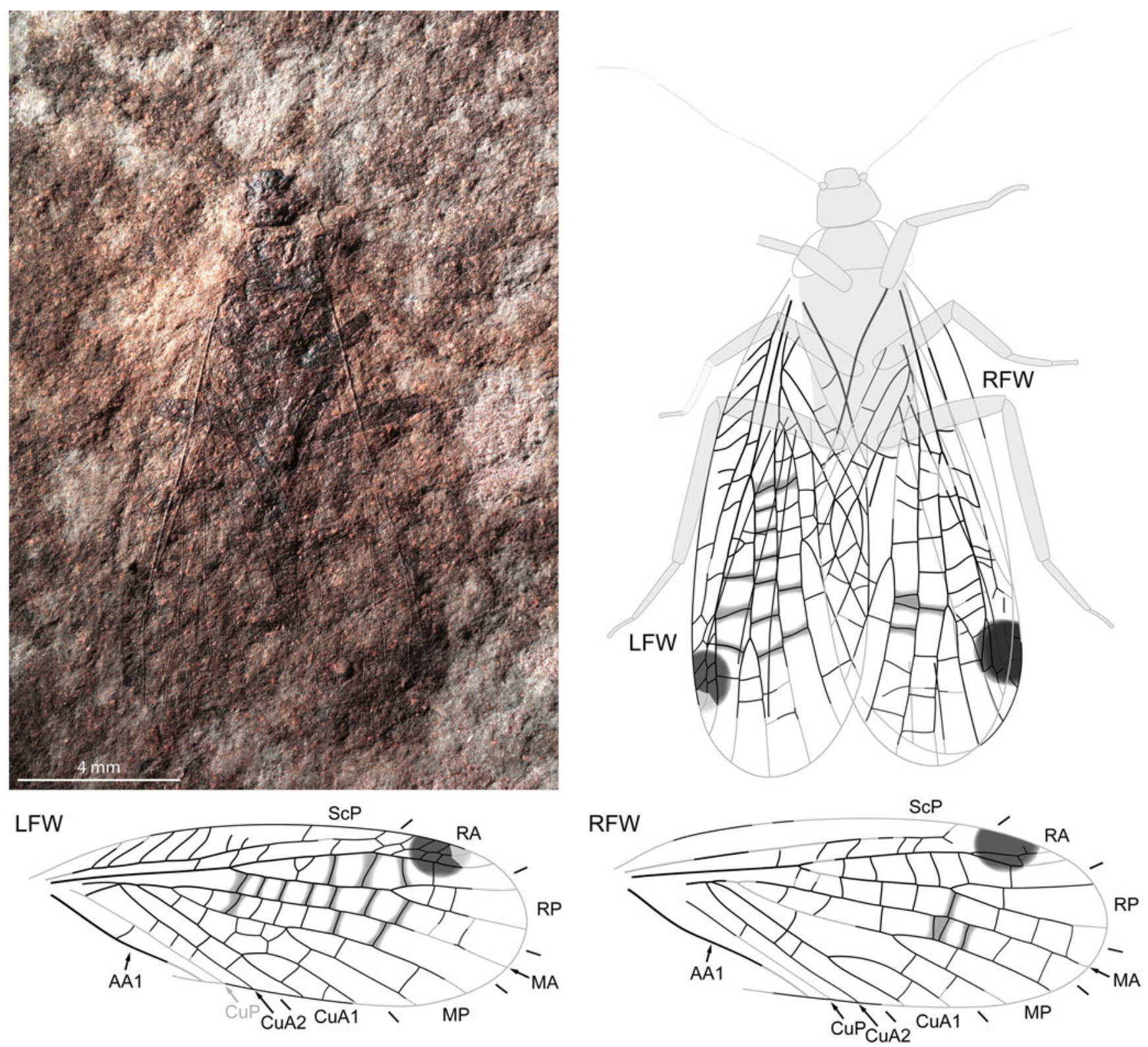

Figure 2. Pictoborella clara n. gen. n. sp., NHMS-WP 6092, photograph (positive imprint, eth.-eth.-dry composite) and reconstructions of complete individual and forewings separated. Abbreviations as in Figure 1. 

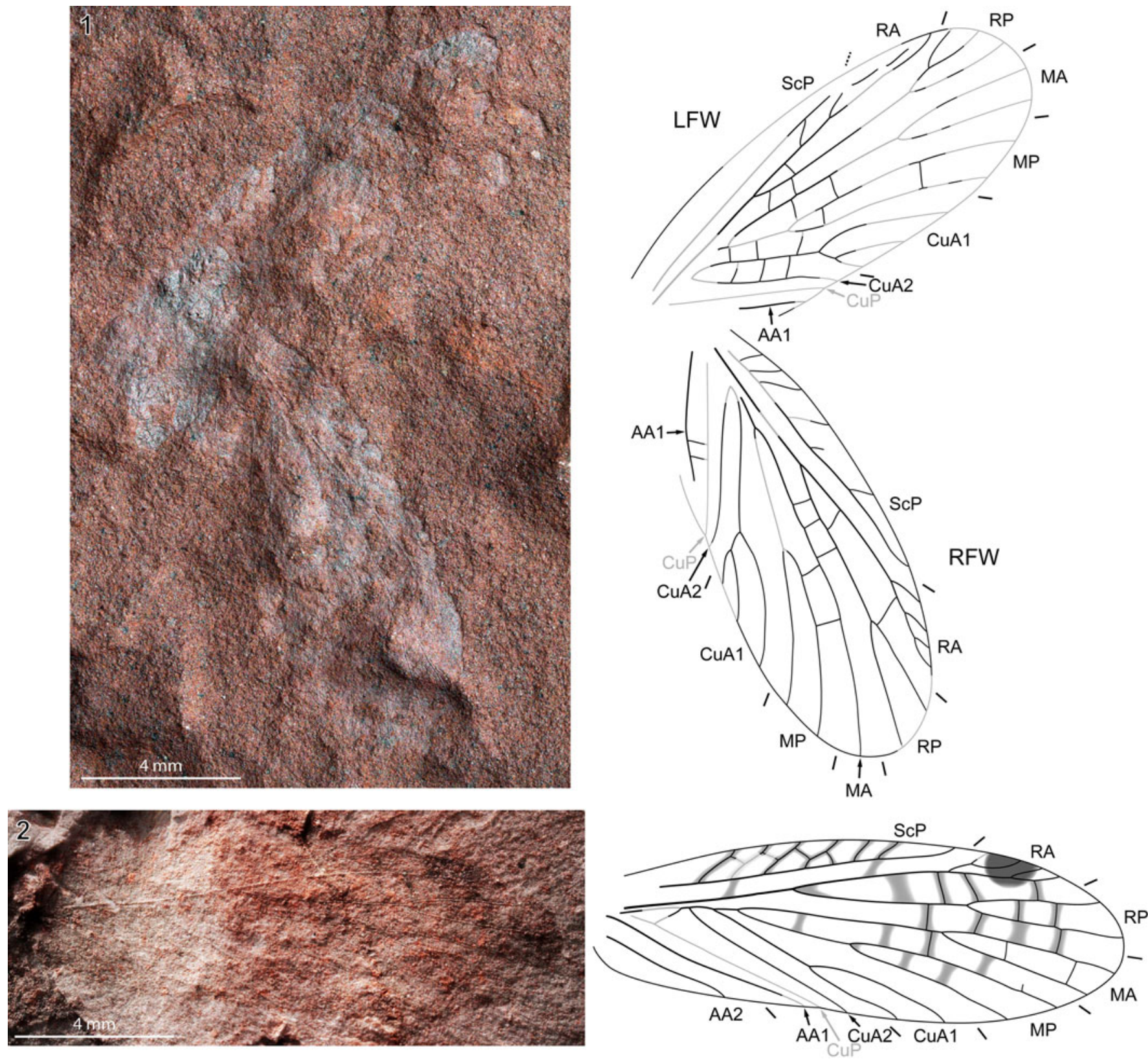

Figure 3. Pictoborella clara n. gen. n. sp.: (1) NHMS-WP 4690, photograph (right forewing as positive imprint, left forewing as negative imprint, eth.-dry composite) and reconstruction; (2) NHMS-WP 5124, photograph (positive imprint, eth.-dry composite) and reconstruction. AA2 = posterior branch(es) of the anterior Analis; other abbreviations as in Figure 1.

occurrence of developed plicatum, area between anterior wing margin and ScP narrower, and earliest position of the RA/RP split.

Body: $\sim 12 \mathrm{~mm}$ long (from head to base of ovipositor; derived from specimen NHMS-WP 5759 only); antennae $\sim 8.3 \mathrm{~mm}$ long, filiform, glabrous; segments setose at least in hindleg tibia and tarsus; in hind leg, on ventral side, occurrence of at least three (probably four, possibly five) sets of paired spines and a tibial spur (possibly paired); ovipositor $\sim 2.5 \mathrm{~mm}$ long, cerci $3.3 \mathrm{~mm}$ long.

Specimen descriptions.-NHMS-Am 7058 (Fig. 1.1; holotype): positive and negative imprints of set composed of nearly complete right and left forewings, and a right hindwing, partly overlapping, and subcircular thoracic elements of undetermined nature; all wings: coloration moderately well preserved, with unpigmented areas clearly visible in the apical area; forewings: $11.8 \mathrm{~mm}$ long, $4.0 \mathrm{~mm}$ wide; RP with two branches, MA simple, MP with three branches (or, a branch of CuA1 translocated onto it), CuA1 with two branches (or three, with one translocated onto MP); left forewing: $\mathrm{CuA} 1$ fork located in a very distal position; right hind wing: plicatum large, in resting position.

NHMS-Am 3237 (Fig. 1.2): positive and negative imprints of a subcomplete right forewing, anal and anterodistal areas missing, $11.4 \mathrm{~mm}$ long as preserved $(\sim 11.7 \mathrm{~mm}$ long if 

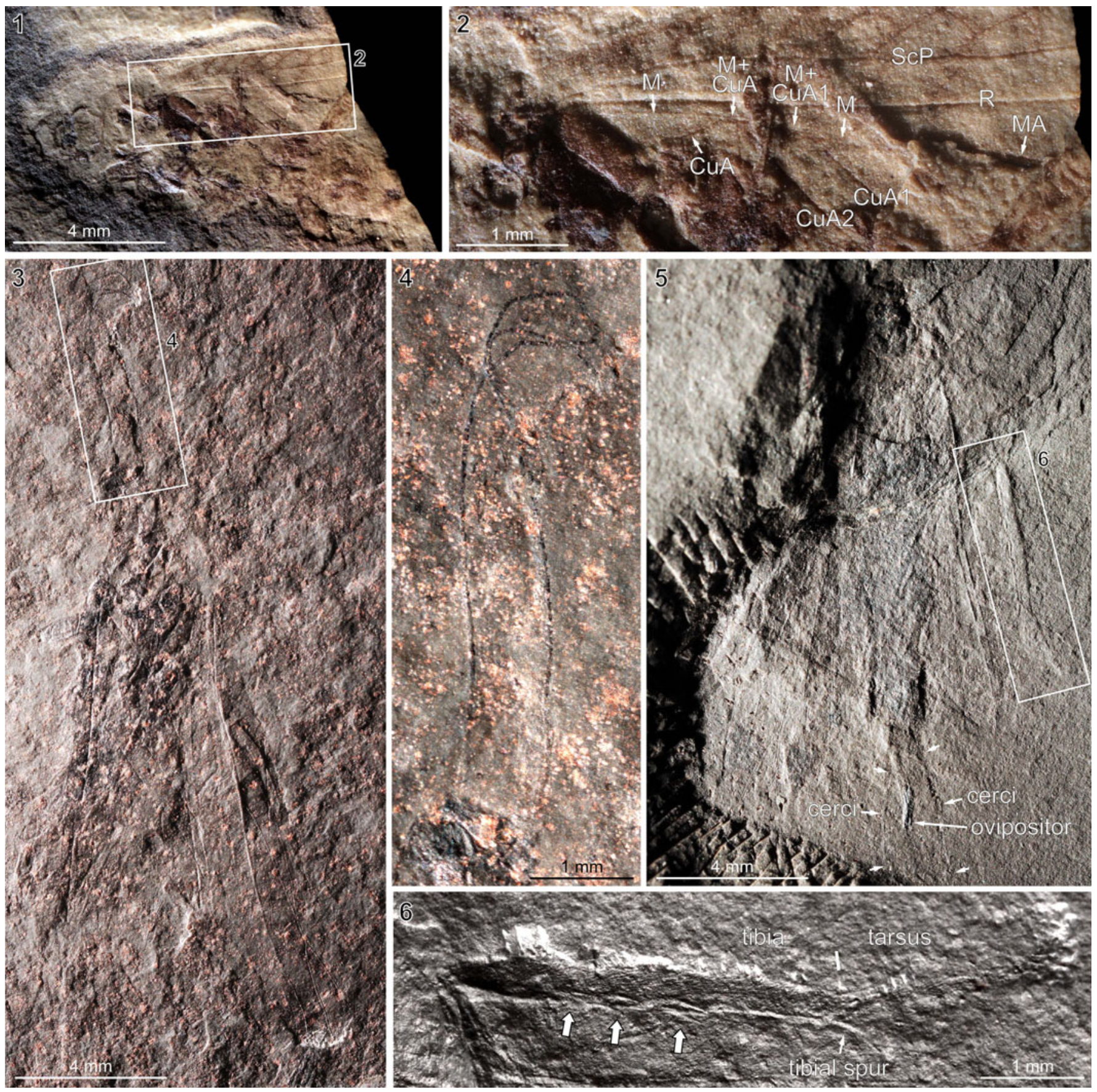

Figure 4. Pictoborella clara n. gen. n. sp.: (1,2) NHMS-Am 3214, photographs (negative imprint, light-mirrored, eth.-dry composites): (1) overview; (2) detail (as indicated in 1) of the left forewing mediocubital area; $(\mathbf{3}, \mathbf{4})$ NHMS-WP 5893, photographs (negative imprint, eth.-eth.-dry composites): (3) overview; (4) detail (as indicated in 1) of antennae; (5,6) NHMS-WP 5759: (5) overview photograph (positive imprint, eth.-dry composite); (6) detail (as indicated in 5) of right hind leg (RTI extract, specular enhancement; large arrows indicate paired ventral spines). $\mathrm{CuA}=$ anterior Cubitus; $\mathrm{M}=\mathrm{Media}$; R, Radius; other abbreviations as in Figure 3.

complete) and $4.0 \mathrm{~mm}$ wide; coloration pattern well preserved, including a well-defined darker anteroapical patch.

NHMS-Am 3246 (Fig. 1.3): positive and negative imprints of a very incomplete left forewing, $7.7 \mathrm{~mm}$ long as preserved, $4.1 \mathrm{~mm}$ wide; coloration pattern very well preserved.

NHMS-Am 3244 (Fig. 1.4): positive imprint of an incomplete right forewing, anal area and various parts missing, $10.9 \mathrm{~mm}$ long as preserved (probably $\sim 13.0 \mathrm{~mm}$ if complete), $4.8 \mathrm{~mm}$ wide; RP with three branches $(2,1)$; crossveins reticulated in area between MP and $\mathrm{CuA1}$; coloration pattern well preserved, with unpigmented areas clearly visible in the apical area.

NHMS-WP 6092 (Fig. 2): positive and negative imprints of an almost complete individual, abdomen apparently missing, wings almost in resting position; forewings: $\sim 12.0 \mathrm{~mm}$ long if complete, $4.4 \mathrm{~mm}$ wide; coloration moderately well preserved; left forewing: $10.7 \mathrm{~mm}$ long as preserved; $\mathrm{CuA}$ fused with $\mathrm{M}$ at the point where it splits into $\mathrm{CuA} 1$ and $\mathrm{CuA} 2$; crossveins reticulated in area between $\mathrm{MP}$ and $\mathrm{CuA} 1$; right forewing: $11.4 \mathrm{~mm}$ long as preserved; body: 

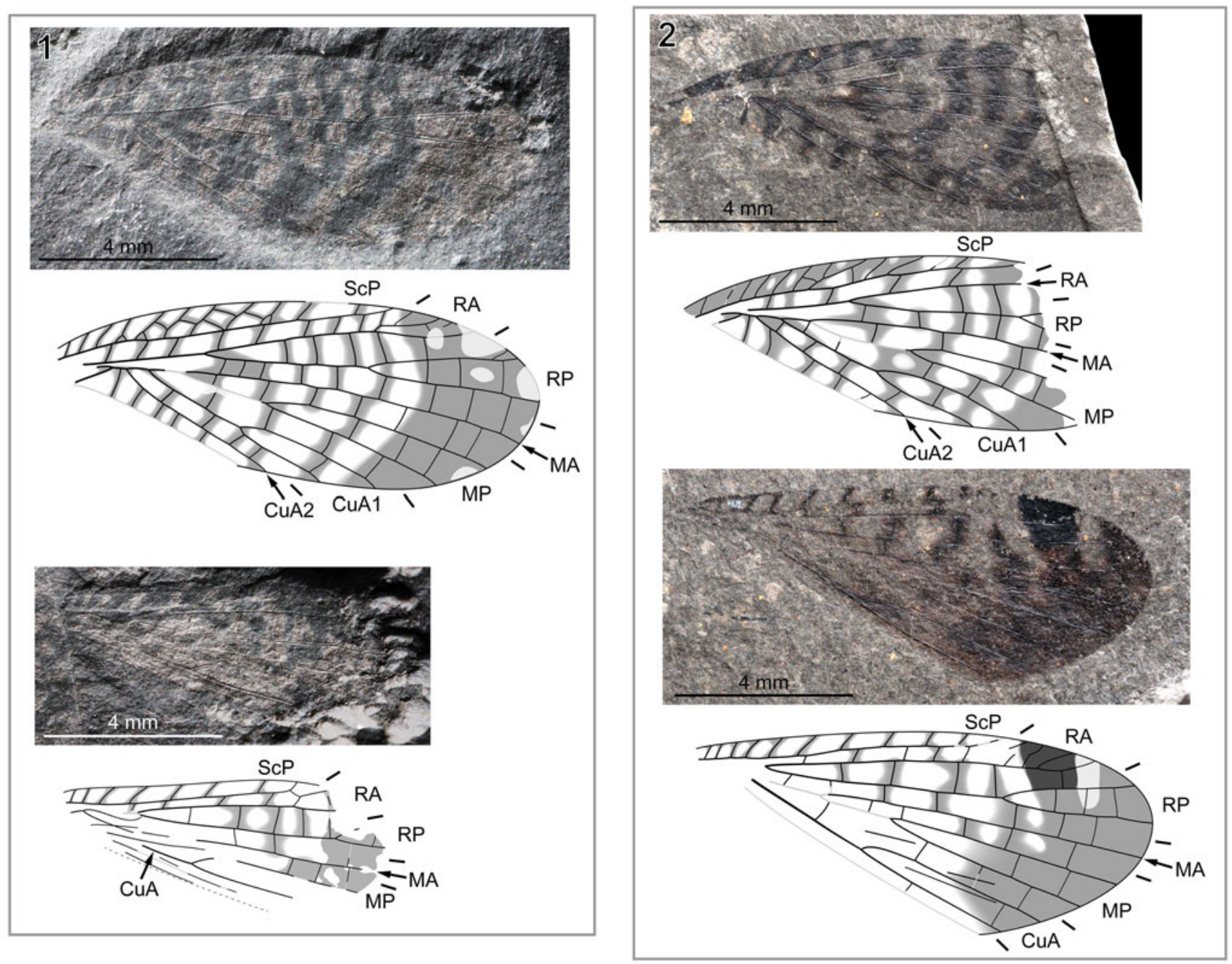

Figure 5. Pictoborella germanica (Prokop et al., 2012) n. comb.: (1) MNHN.F.A31034, holotype, right forewing photograph (positive imprint, eth.-dry composite), right hindwing photograph (positive imprint, eth.-dry composite), and reconstructions; (2) MNHN.F.A31035, paratype, right forewing photograph (positive imprint, flipped horizontally, eth.-dry composite), right hindwing photograph (negative imprint, flipped horizontally, eth.-dry composite), and reconstructions. Abbreviations as in Figure 4.

antennae $\sim 6.4 \mathrm{~mm}$ long as preserved; foreleg: femur $1.6 \mathrm{~mm}$ long, tibia $2.0 \mathrm{~mm}$ long, tarsus $1.0 \mathrm{~mm}$ long; midleg: femur $2.4 \mathrm{~mm}$ long, tibia $1.8 \mathrm{~mm}$ long, tarsus $1.7 \mathrm{~mm}$ long; hindleg: femur 3.2 $\mathrm{mm}$ long, tibia $4.0 \mathrm{~mm}$ long, tarsus $2.5 \mathrm{~mm}$ long.

NHMS-WP 4690 (Fig. 3.1): positive and negative imprints of a pair of forewings attached to a pterothorax; both forewings: MP with two branches; CuA with three branches $(1,2)$; left forewing: very incomplete; RP with first fork located in very distal position, and three branches $(2,1)$; MA forked; right forewing: almost complete, $11.7 \mathrm{~mm}$ long, $4.5 \mathrm{~mm}$ wide; $\mathrm{RP}$ with two branches, MA simple; coloration pattern moderately well preserved, with unpigmented patches visible in the apical area.

NHMS-WP 5124 (Fig. 3.2): positive and negative imprints of a subcomplete right forewing, moderately well preserved, $13.4 \mathrm{~mm}$ long, $4.4 \mathrm{~mm}$ wide; RP, MA, MP, and $\mathrm{CuA} 1$ with two branches each; $\mathrm{CuA}$ fused with $\mathrm{M} 0.2 \mathrm{~mm}$ before it splits into $\mathrm{CuA} 1$ and $\mathrm{CuA} 2$; coloration pattern moderately well preserved, with unpigmented patches visible in the apical area.

NHMS-Am 3214 (Fig. 4.1, 4.2): positive and negative imprints of an individual preserving head, thoracic elements, and base of left forewing; left forewing: bases of $\mathrm{M}$ and $\mathrm{CuA}$ clearly visible, fusing into $\mathrm{M}+\mathrm{CuA}$ stem and continuing into $\mathrm{M}+\mathrm{CuA} 1$ stem after divergence of $\mathrm{CuA} 2$; coloration pattern well preserved; fine setae present on entire preserved area of forewing.

NHMS-WP 5893 (Fig. 4.3, 4.4): positive and negative imprints of subcomplete individual, abdomen probably missing; left forewing well preserved but creased more or less along its longitudinal axis, coloration well preserved; antennae well preserved.

NHMS-WP 5759 (Fig. 4.5, 4.6): positive and negative imprints of moderately well preserved subcomplete individual, with wings in resting position; dark anteroapical patch conspicuous in left fore- and hindwing; tibia and tarsus of right hindleg well exposed and well preserved; ovipositor and cerci moderately well preserved, long.

Etymology.—clara: L. clear or bright; referring to the occurrence of unpigmented patches in the fore- and hindwing apical area. 

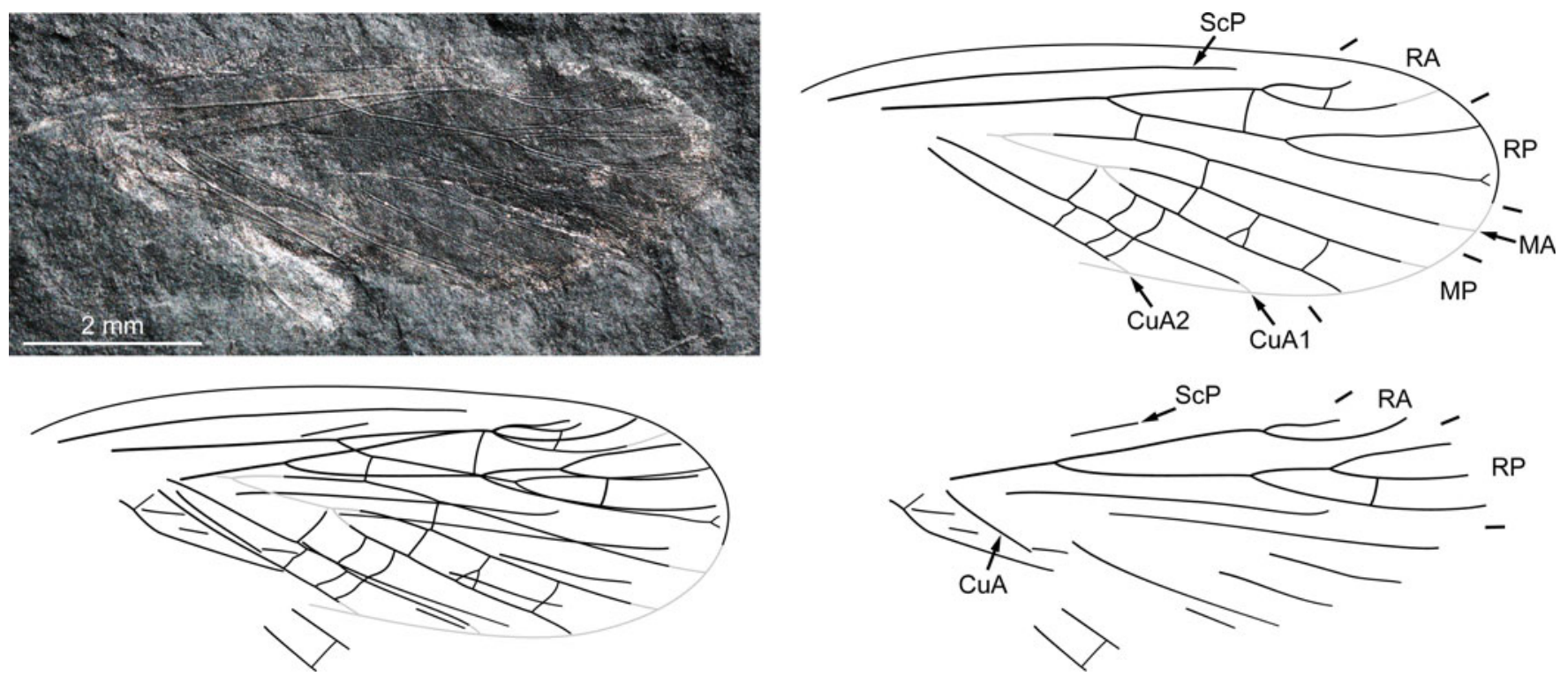

Figure 6. Oborella brauckmanni Prokop et al., 2012, MNHN.F.A31044, holotype, photograph (positive imprint, flipped horizontally, eth.-dry composite), and reconstructions of left fore- and hindwing in resting position and separated. Abbreviations as in Figure 4.
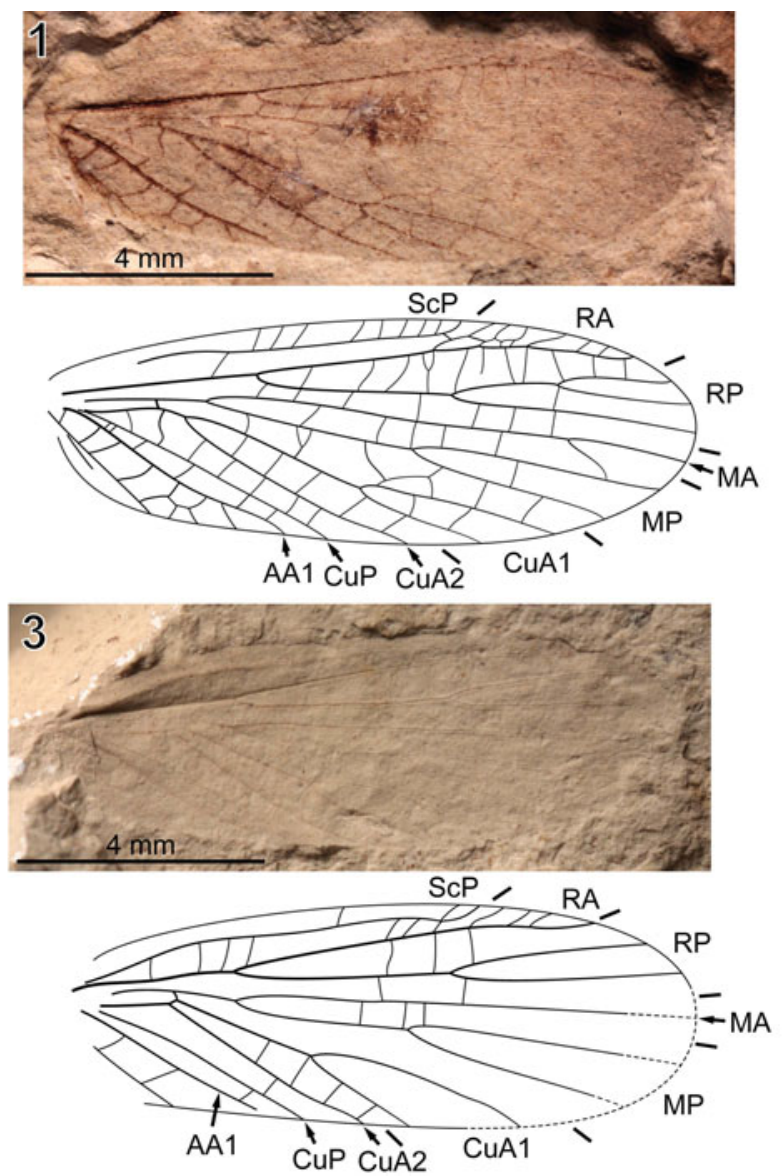
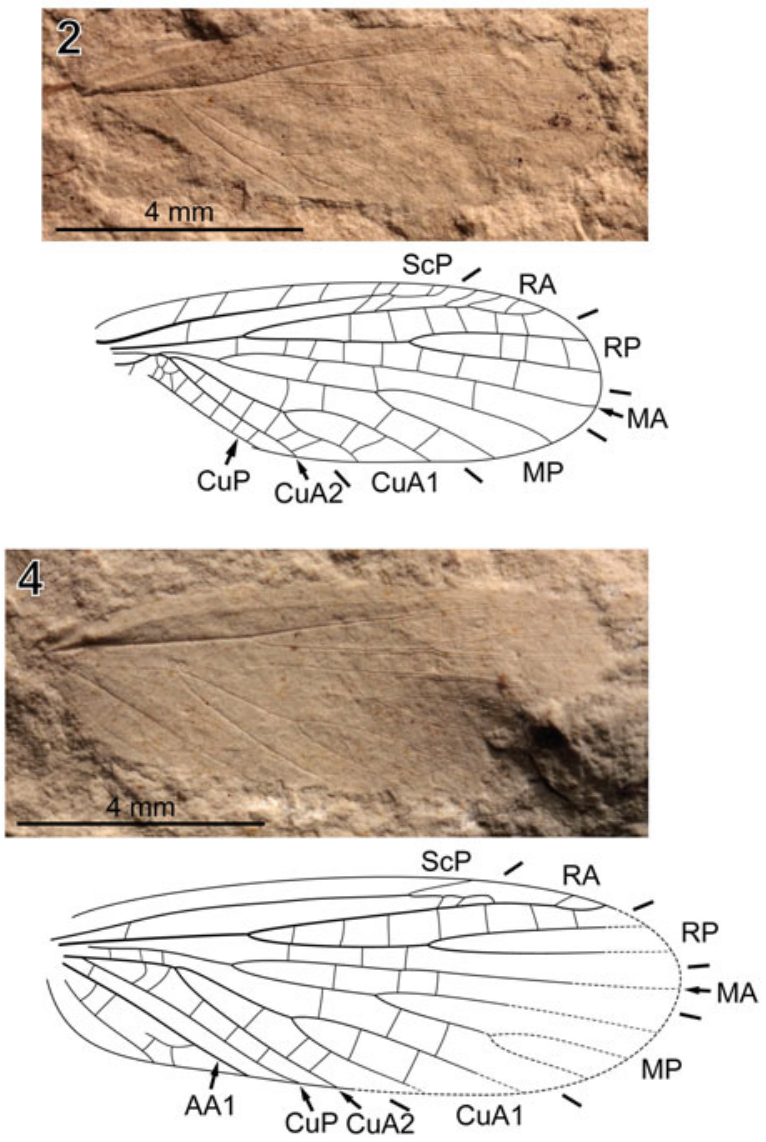

Figure 7. Artinska clara Sellards, 1909: (1) MCZ 3568, neotype, right forewing, photograph (negative imprint, flipped horizontally, eth.-dry composite) and reconstruction; (2) MCZ 13051, right forewing, photograph (negative imprint, flipped horizontally, eth.-dry composite) and reconstruction; (3) MCZ 13066, left forewing, photograph (negative imprint, eth.-dry composite) and reconstruction; (4) MCZ 13143, right forewing, photograph (negative imprint, flipped horizontally, eth.-dry composite) and reconstruction. Abbreviations as in Figure 4. 
Materials.-NHMS-Am 7058, holotype (Fig. 1.1); 3210; 3214 (Fig. 4.1, 4.2); 3237 (Fig. 1.2); 3244 (Fig. 1.4); 3246 (Fig. 1.3); 3264; and 4430. NHMS-WP 4690 (Fig. 3.1); 5124 (Fig. 3.2); 5759 (Fig. 4.5, 4.6); 5893 (Fig. 4.3, 4.4); 6092 (Fig. 2); 6210; 6331; and 11308. See Table 1 for locality information.

Remarks. - Some variations in venation pattern and size were observed among the specimens herein assigned to Pictoborella clara n. gen. n. sp. Notably, RP, MP, and CuA1 usually possess two branches each, but can occasionally display three; MA is usually simple, but can occasionally be forked. A similar range of variability is known to occur within Artinska clara Sellards, 1909 (see Carpenter, 1935 and Fig. 7), a Lemmatophoridae species comparable to species of Pictoborella n. gen. This suggests that all considered specimens belong to a single species.

Our new data show that Pictoborella germanica (Fig. 5) and the new species are very similar (hence their assignment to a new genus). However, in Pictoborella germanica, the apical area of both fore- and hindwing displays a continuously dark area that is not present in the new material (from both Sperbersbach and Cabarz; see in particular Fig 1.1, 1.4, 3.1, 3.2), which justifies the erection of new species.

\section{Family Liomopteridae Sellards, 1909}

Remarks.-Assignment to this genus-rich family is essentially based on the lack of distinctive character states and/or homoplastic character states (Carpenter, 1992; Storozhenko, 1998, 2002). This situation, coupled with incomplete documentation of intraindividual variability for many of the known species, renders the systematics of the Liomopteridae arduous. The proposed assignment of new material to this family rests on the combination, in the forewing, of a comparatively broad area between the anterior wing margin and ScP, a lack of connection between $\mathrm{CuA}$ and $\mathrm{M}$, and a branched MA.

\section{Genus Liomopterum Sellards, 1909}

Type species.-Liomopterum ornatum Sellards, 1909, Kansas and Oklahoma, USA; Wellington Formation, early Permian.

Other species.-Liomopterum sellardsi Carpenter, 1950 and Liomopterum elongatum (Sellards, 1909), both from Kansas and Oklahoma, USA, Wellington Formation, early Permian); Liomopterum fuscatum n. sp., from Cabarz and Sperbersbach, Germany, Goldlauter Formation, early Permian; and Liomopterum thuringiensis n. sp., from Cabarz, Germany, Goldlauter Formation, early Permian.

Remarks.-The assignment of a new species to the genus Liomopterum is based on the following combination of character states: (1) crossveins in the area between the anterior wing margin and ScP simple, without crossveins between them, and (2) crossveins in the RA-RP area scalariform (as opposed to reticulate) (Storozhenko, 1998). The genera Liomopterum and Liomopterites Sharov, 1961, which share these states, are differentiated based on the presence, or lack thereof, respectively, of reticulated crossveins in the basal part of the CuA-CuP area (Sharov, 1961; Storozhenko, 1998). Even though this state could not be appreciated in all of the available material, it clearly relates to the course of $\mathrm{CuA}$ in its basal portion, either strongly bent toward $\mathrm{M}$ (in which case the basal part of the $\mathrm{CuA}-\mathrm{CuP}$ area is broad, providing room for reticulation) or more rectilinear (in which case the basal part of the $\mathrm{CuA}-\mathrm{CuP}$ area is not particularly broad). Judging from the course of $\mathrm{CuA}$ in its basal portion, the new material conforms the condition known in Liomopterum.

\section{Liomopterum fuscatum new species} Figures 8-10

Holotype.-NHMS-WP 6386, from Sperbersbach, Germany; early Permian (Fig. 8.1).

Diagnosis.-Small (forewing $\sim 11.5 \mathrm{~mm}$ long); in forewing, MA with two or three branches; first fork of $\mathrm{CuA}$ in basal position; $\mathrm{CuA} 1$ and its branches rectilinear; forewing (and possibly hindwing, at least in part) with uniform dark pigmentation.

Occurrence.-Cabarz and Sperbersbach, Germany; Goldlauter Formation, early Permian.

Description.—Forewing: $10.6-12.1 \mathrm{~mm}$ long, $\quad 3.7-4.4 \mathrm{~mm}$ wide; ScP reaching anterior wing margin slightly basal or opposite to second third of wing length (rarely distal to it); veinlets between anterior wing margin and $\mathrm{ScP}$ well developed, mostly simple; RA/RP fork usually located basal to first third of wing length (rarely distal to it); RA terminating with four or five anterior, very oblique, simple veinlets reaching anterior wing margin; first fork of RP slightly basal to second third of wing length; RP usually with three branches (rarely four); MA with two or three branches (rarely simple); if branched, fist fork of MA usually earlier than that of RP; MP with two branches (rarely three), with first fork later than that of $\mathrm{R}$ and earlier than those of RP and MA; CuA directed toward $\mathrm{M}$ but remaining distinct from it, yet closely approaching it; $\mathrm{CuA}$ forked into $\mathrm{CuA} 1$ and $\mathrm{CuA} 2$ close to the point where it approximates $\mathrm{M}$; CuA1 with two branches, rectilinear; $\mathrm{CuA} 2$ simple; areas between $\mathrm{MP}$ and fork of $\mathrm{CuA} 1$, and between fork of $\mathrm{CuA}$ and $\mathrm{CuP}$ broad; $\mathrm{CuP}$ weak, straight; AA1 strong, simple; crossveins numerous, scalariform, except in broadest areas where they reticulate; pigmentation uniform, dark.

Body: $\sim 13.5 \mathrm{~mm}$ long (from head to base of ovipositor; derived from specimen NHMS-WP 7834 only); antennae and cerci setose; cerci very long.

Specimen descriptions.-NHMS-WP 6386 (Fig. 8.1; holotype): positive and negative imprints of a subcomplete pair of forewings in resting position, with anterodistal portion of left hindwing visible; both forewings: RP with three branches $(2,1)$, MP and CuA1 with two branches each; left forewing: $10.6 \mathrm{~mm}$ long as preserved ( $\sim 11.2 \mathrm{~mm}$ if complete), $\sim 4.0 \mathrm{~mm}$ wide; anterior branch of RP forked very distally; MA with three branches $(2,1)$; right forewing: $11.2 \mathrm{~mm}$ long, $4.0 \mathrm{~mm}$ wide; MA with 

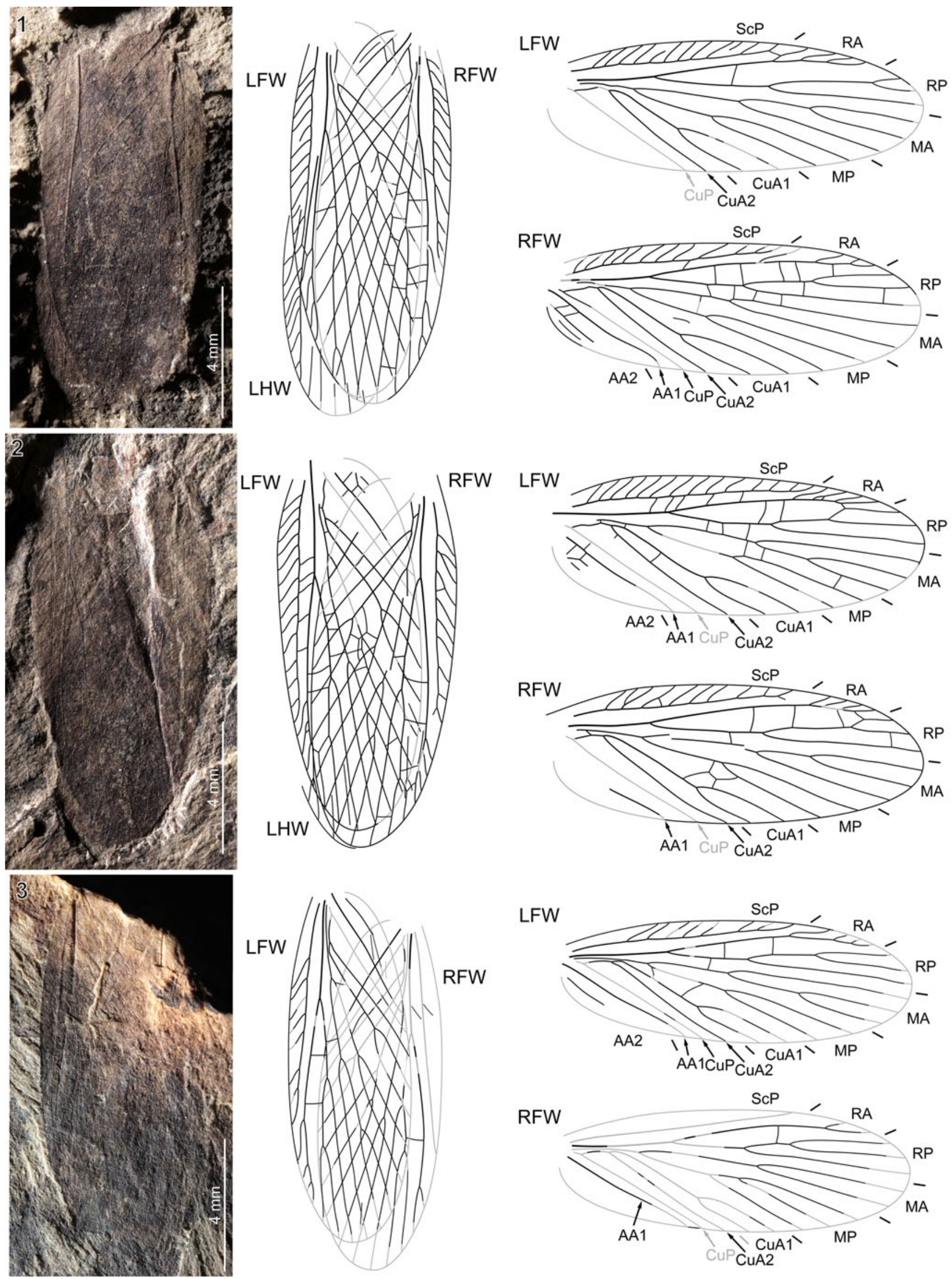
Figure 8. Liomopterum fuscatum n. sp.: (1) NHMS-WP 6386, holotype, photograph (positive imprint, eth.-dry composite) and reconstructions of all wings in resting position and forewings separated; (2) NHMS-WP 6199, photograph (positive imprint, eth.-dry composite) and reconstructions of all wings in resting position and forewings separated; (3) NHMS-Am 3730, photograph (negative imprint, light-mirrored, flipped horizontally, eth.-dry composite) and reconstructions of all wings in resting position and forewings separated. LHW = left hindwing; other abbreviations as in Figure 4.

two branches; basal portion of CuP discernible; AA1 strong, simple, slightly sigmoidal; two AA2 branches partly preserved.

NHMS-WP 6199 (Fig. 8.2): positive imprint of a subcomplete pair of forewings in resting position, with small portion of left hindwing apex visible; both forewings: $11.3 \mathrm{~mm}$ long, $4.1 \mathrm{~mm}$ wide; RP with three branches $(2,1)$, the anteriormost one approximating RA; MP and CuA1 with two branches each; left forewing: MA with three branches $(1,2)$; right forewing: MA with three branches $(2,1)$; area between MP and $\mathrm{CuA}$ with reticulated crossveins.

NHMS-Am 3730 (Fig. 8.3): negative imprint of a pair of forewings in resting position, right forewing very incompletely discernible; both forewings: RP with three branches $(2,1)$; left forewing: $10.4 \mathrm{~mm}$ long ( 10.6 $\mathrm{mm}$ if complete), $\sim 3.7 \mathrm{~mm}$ wide; course of $\mathrm{M}$ very clear in basal part, distinct from $\mathrm{CuA}$; $\mathrm{M}$ and $\mathrm{CuA} 1$ briefly approximating; MA with three branches $(1,2)$; MP and $\mathrm{CuA} 1$ with two branches each; right forewing: MA with two branches; MP with three branches $(2,1)$.

NHMS-WP 7961 (Fig. 9.1): positive and negative imprints of a pair of forewings in resting position; both forewings: 12.1 $\mathrm{mm}$ long, $4.2 \mathrm{~mm}$ wide; MA simple, MP and $\mathrm{CuA} 1$ with two branches each; left forewing: RP with four branches $(2,2)$; right forewing: RP with three branches $(2,1)$.

NHMS-WP 5984 (Fig. 9.2): positive and negative imprints of well-preserved complete individual with wings in resting position, abdomen undiscernible; both forewings: $12.0 \mathrm{~mm}$ long, $\sim 4.4 \mathrm{~mm}$ wide; MA, MP, and CuA1 with two branches each; pigmentation uniform, dark; left forewing: RP with three branches $(2,1)$; right forewing: RP posteriorly pectinate, with four branches; fork of $\mathrm{CuA} 1$ located distally; both hindwings: sharp inflexion of $\mathrm{R}$ at $\mathrm{RA} / \mathrm{RP}$ split; right hindwing: RP posteriorly pectinate, with four branches.

NHMS-WP 7834 (Fig. 10): positive and negative imprints of a well preserved, subcomplete individual, wing apices indistinct; right forewing: $\mathrm{M}$ clearly distinct from $\mathrm{CuA}$; as preserved, $\mathrm{RP}$, MA, MP, and CuA1 with two branches each; left forewing: slight, uniform pigmentation preserved; body: $13.5 \mathrm{~mm}$ long (from head to end of abdomen); antennae $4.4 \mathrm{~mm}$ long (as exposed), setose; cerci mostly well exposed, $5.6 \mathrm{~mm}$ long (as exposed), setose.

Etymology.—fuscatum: L., smoked; referring to the uniform, dark coloration of the forewing.

Materials.-NHMS-WP 6386, holotype (Fig. 8.1); 6199 (Fig. 8.2); 6440; 6641; 7961 (Fig. 9.1); 7964; 5984 (Fig. 9.2); 6155; and 7834 ab (Fig. 10). NHMS-Am 3730 (Fig. 8.3). See Table 1 for locality information.

Remarks.-The available sample, including five individuals preserving more or less complete forewing pairs, provides a rare opportunity to assess intraspecific variability based on the intraindividual one. For example, the number of MA branches (three versus two) varies within a single individual (Fig. 8.1, 8.3), as well as its branching pattern (1,2 versus 2,1; Fig. 8.2).
Although the peculiar coloration of the forewing is very conspicuous in material from Sperbersbach, it is less so in material from Cabarz. In specimen NHMS-WP 5984, the merging of photographs of both sides under a thin film of ethanol proved decisive. It is doubtless that all specimens belong to the same species.

The new material differs from all known species of Liomopterum in its uniform, dark coloration pattern in the forewing. Furthermore, compared with known Liomopterum species, the new material can be easily distinguished by size, being smaller than Liomopterum ornatum and distinctly smaller than Liomopterum sellardsi and Liomopterum elongatum (see Carpenter, 1950; Figs. 11, 12). Additionally, the new material displays a more basal split of the $\mathrm{CuA} 1 / \mathrm{CuA} 2$ than in Liomopterum ornatum (Fig. 11) and Liomopterum elongatum (see Carpenter, 1950, fig. 3B). Finally, CuA1 is more rectilinear (versus sigmoidal) than in other Liomopterum species (see Carpenter, 1950, figs. 1, 3B, 4; Figs. 11, 12). This trait also occurs in some species assigned to the genus Liomopterites. Among them, Liomopterites germanicus Brauckmann and Willmann, 1990, in which the forewing base is unknown (and therefore might belong to Liomopterum), shares many traits with the new material, including small size. However, in the new material, the first fork of MA is commonly located basal to the first fork of RP, although it is clearly distal to the latter in Liomopterites germanicus. This trait, not usually observed in Liomopterum spp. (Carpenter, 1950; Figs. 11-12), suggests that the new material cannot be assigned to Liomopterites germanicus. Furthermore, the latter lacks the uniform, dark coloration.

The recently described species Oborella monsjovisensis shares some traits with the new material, e.g., a branched MA (present in most of the new specimens) and $\mathrm{CuA}$ approaching $\mathrm{M}$ very closely. It was therefore considered here. In the forewing, this species displays a pigmented area running along the posterior edge to the apex, whereas the new material is uniformly pigmented. Moreover, the forewing of $O$. monsjovisensis is larger than that of the new specimens, $\sim 14.7 \mathrm{~mm}$ long (Poschmann and Nel, 2020; versus 10.6-12.0 $\mathrm{mm}$ long for the new material). In summary, available evidence suggests that the new material belongs to a new species assigned to the genus Liomopterum.

Genus Uralioma Storozhenko and Aristov, 1999

Type species.—Uralioma variabilis Storozhenko and Aristov, 1999, Sylva River, Chekarda, Perm Region, Russian Federation; Koshelevka Formation, early Permian.

Uralioma thuringiensis new species Figure 13

Holotype.-NHS-WP 5850, from Cabarz, Germany; early Permian (Fig. 13). 

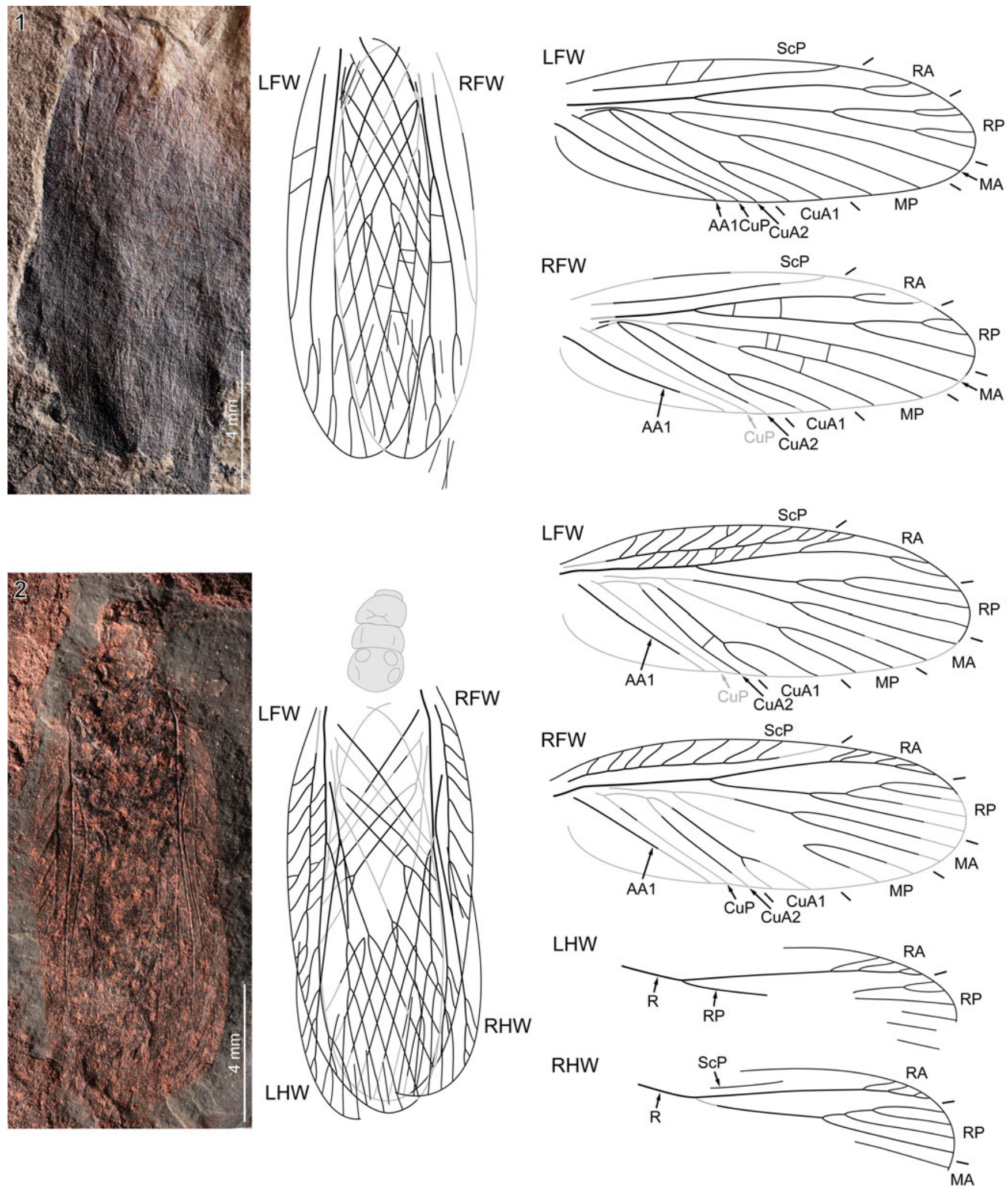

Figure 9. Liomopterum fuscatum n. sp.: (1) NHMS-WP 7961, photograph (positive imprint, eth.-dry composite) and reconstructions of all wings in resting position and forewings separated; (2) NHMS-WP 5984, photograph (negative imprint, light-mirrored, flipped horizontally, eth.-eth.-dry composite) and reconstructions of all wings in resting position and fore- and hindwings separated. Abbreviations as in Figure 8. 

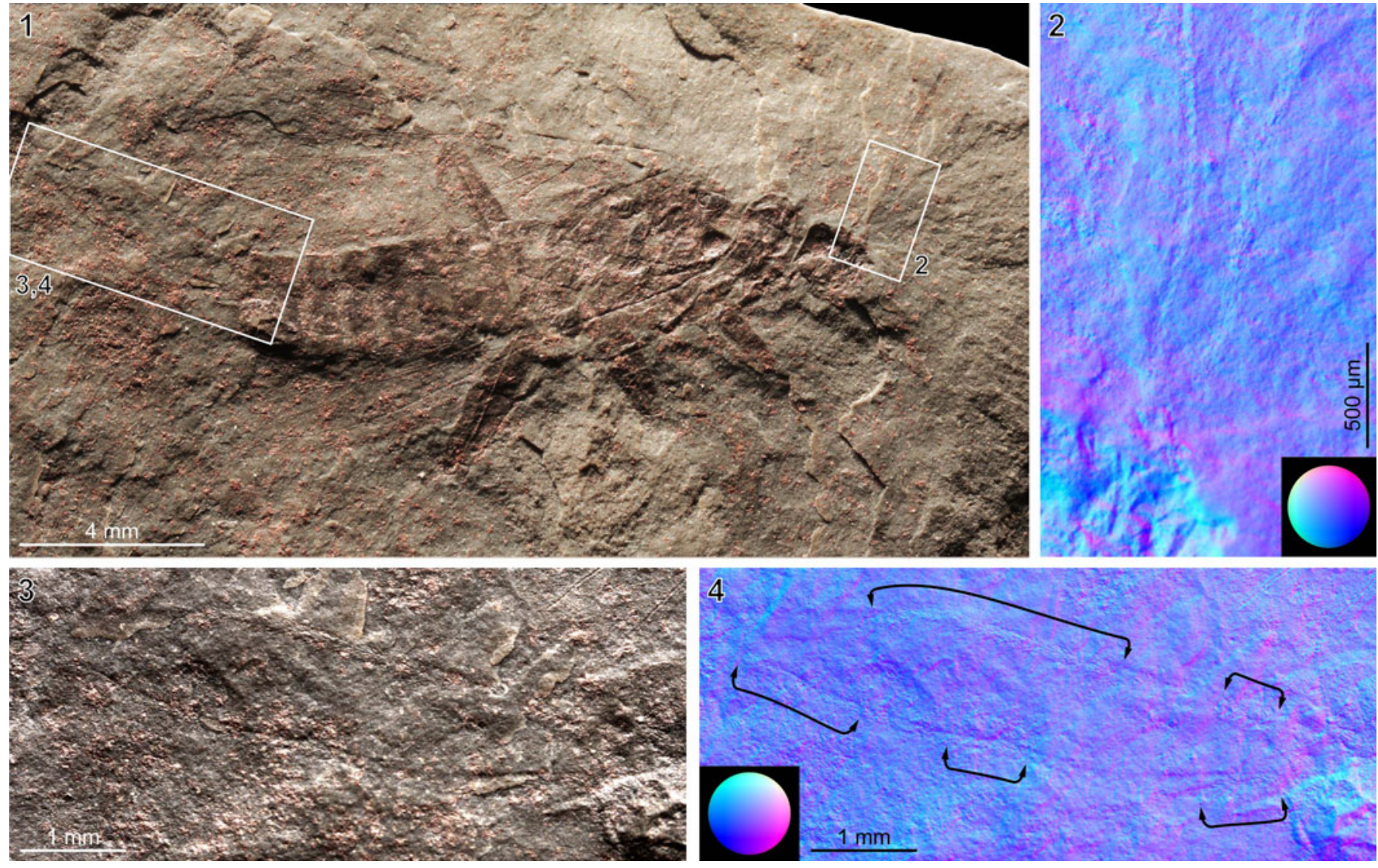

Figure 10. Liomopterum fuscatum n. sp., NHMS-WP 7834: (1) overview photograph (negative imprint, eth.-dry composite); (2) detail (as indicated in 1) of antennae, RTI extract (see Dryad Digital Repository; normals visualization); $(\mathbf{3}, \mathbf{4})$ detail (as indicated in 1) of cerci, RTI extracts (see Dryad Digital Repository) under $(\mathbf{3})$ specular enhancement and (4) normals visualization (double-arrowed brackets indicate areas where setation is well exposed).

Diagnosis. - In forewing, area between anterior margin and ScP very wide; location of $\mathrm{CuA} 1 / \mathrm{CuA} 2$ fork basal; MA with two branches.

Occurrence.-Cabarz, Germany; Goldlauter Formation; early Permian.

Description.-NHMS-WP 5850 (Fig. 13): positive and negative imprints of well-preserved right forewing, $15.1 \mathrm{~mm}$ long as preserved $(\sim 16.0 \mathrm{~mm}$ if complete) $5.6 \mathrm{~mm}$ wide; $\mathrm{ScP}$ reaching anterior wing margin slightly basal to second third of wing length; veinlets between anterior wing margin and ScP well developed, simple, without crossveins between them; R forked into RA and RP distal to first third of wing length; RA with veinlets reaching anterior wing margin; first fork of RP opposite to second third of wing length; RP with four branches $(2,2)$; MA forked earlier than RP; MA with two branches; MP with two branches, fork located earlier than that of RP and later than those of R and MA; $\mathrm{CuA}$ forked earlier than $\mathrm{M}$, strongly bent toward $\mathrm{M}$ before it forks into $\mathrm{CuA} 1$ and $\mathrm{CuA} 2$; $\mathrm{CuA} 1$ with two branches, stem and branches (notably anterior one) sigmoidal; $\mathrm{CuA} 2$ simple; crossveins numerous, mostly scalariform, reticulated in areas between $\mathrm{CuA}$ and $\mathrm{CuP}$, between MP and $\mathrm{CuA} 1$, and between $\mathrm{RA}$ and RP, and absent between $\mathrm{ScP}$ veinlets; membrane uniformly hyaline.
Etymology.-The specific epithet refers to Thuringia, the German state from which the holotype was recovered.

Material.—Holotype only.

Remarks.-NHMS-WP 5850 shares many traits with species currently assigned to the genus Liomopterum, in particular a comparatively broad area between the anterior wing margin and $\mathrm{ScP}$, filled with simple veinlets, and the sigmoidal course of $\mathrm{CuA} 1$, a trait shared with Liomopterum ornatum (see Carpenter, 1950, fig. 1; Fig. 11), Liomopterum elongatum (see Carpenter, 1950, fig. 3B), and Liomopterum sellardsi (see Carpenter, 1950, fig. 4; Fig. 12). However, the area between the anterior wing margin and $\mathrm{ScP}$ is comparatively broader than in any known Liomopterum species. This led us to compare the new material with Uralioma variabilis (Chekarda, Russian Federation; early Permian), overly very similar to Liomopterum spp. but displaying the broader $\mathrm{ScP}$ area and a more strongly sigmoidal $\mathrm{CuA} 1$, as observed in the new material. The main difference regards the occurrence of crossveins between $\mathrm{ScP}$ veinlets, usually present in $U$. variabilis but absent in the new material. This difference can be regarded as of specific relevance and/or a consequence of the comparatively smaller size of the new material (forewing $26-32 \mathrm{~mm}$ long in U. variabilis, versus $\sim 16.0 \mathrm{~mm}$ in the new material). 

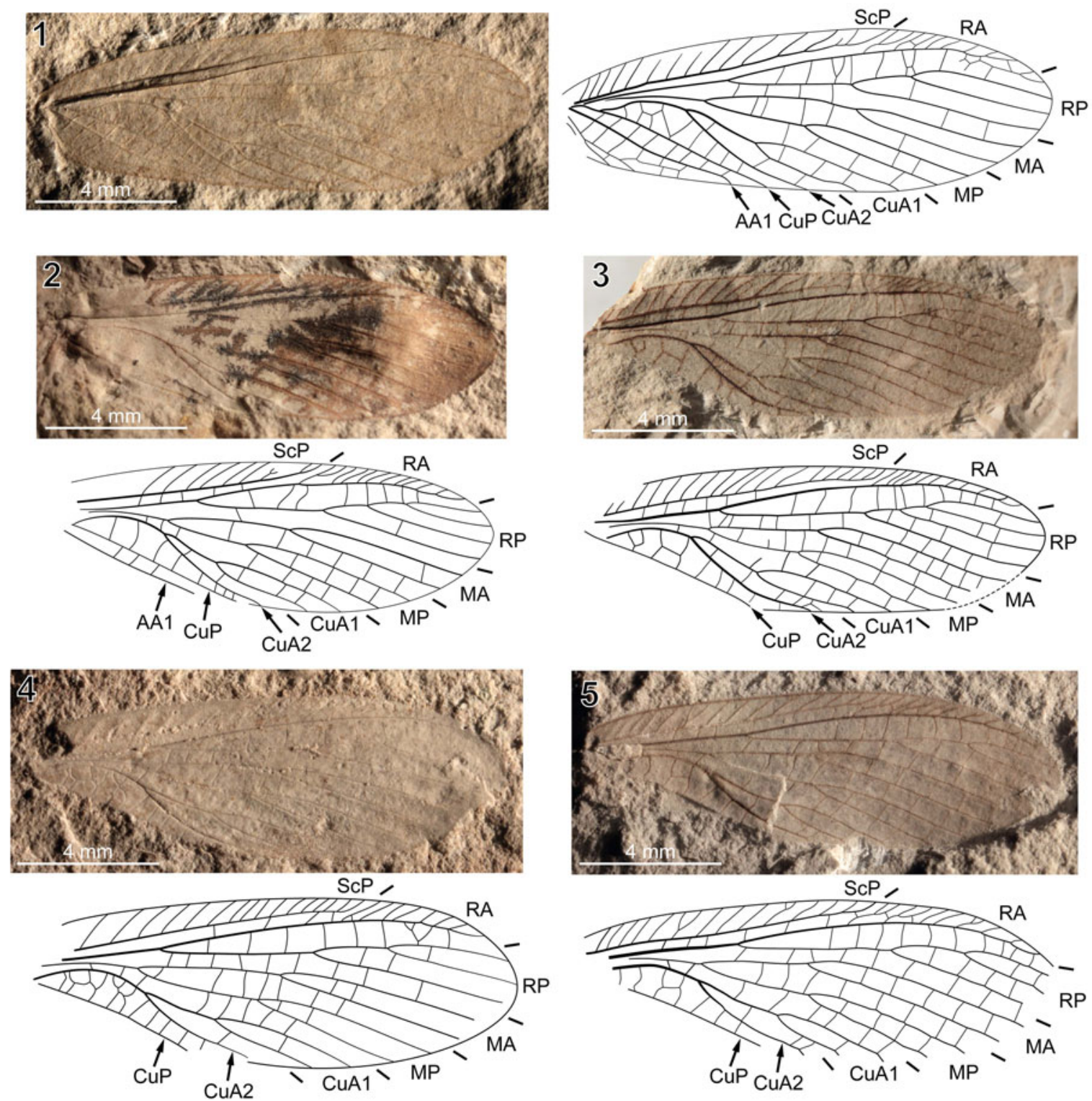

Figure 11. Liomopterum ornatum Sellards, 1909: (1) MCZ 4830, left forewing, photograph (negative imprint, eth.-dry composite) and reconstruction; (2) MCZ 4834, right forewing, photograph (negative imprint, flipped horizontally, eth.-dry composite) and reconstruction; (3) MCZ 4829, right forewing, photograph (positive imprint, eth.-dry composite) and reconstruction; (4) MCZ 11164, right forewing, photograph (negative imprint, flipped horizontally, eth.-dry composite) and reconstruction; (5) MCZ 11229, right forewing, photograph (negative imprint, flipped horizontally, eth.-dry composite) and reconstruction. Abbreviations as in Figure 8.

Comparison with U. maxima Aristov, 2004, the second of the two species currently assigned to Uralioma, is made unclear by the lack of available data on this species. In any case, it is much larger than the new material (forewing $18 \mathrm{~mm}$ wide versus 5.6 $\mathrm{mm}$ ). Given this combination of traits, and despite the paucity of available material, we propose to erect a new species assigned to Uralioma.

Genus Liomopterites Sharov, 1961

Type species.—Liomopterites expectus Sharov, 1961, Kaltan, Siberia, Russian Federation; Kuznetsk Formation, early Permian.

Liomopterites sperbersbachensis new species Figure 14
Holotype-NHMS-Am 3212, from Sperbersbach, Germany; early Permian (Fig. 14).

Diagnosis. - In forewing, RP with three branches, MA with two branches, MP with three branches, CuA1 with three branches; $\sim 16.4 \mathrm{~mm}$ long.

Occurrence.-Cabarz, Germany; Goldlauter Formation, early Permian.

Description.-NHMS-Am 3212 (Fig. 14): negative and positive imprints of a well-preserved right forewing, basal quarter and clavus missing; $14.1 \mathrm{~mm}$ long as preserved $(\sim 16.4 \mathrm{~mm}$ if complete), $5.9 \mathrm{~mm}$ wide; area between anterior wing margin and $\mathrm{ScP}$ narrow; $\mathrm{ScP}$ veinlets very oblique; termination of $\mathrm{ScP}$ unclear as consequence of merging with anterior RA veinlets; 

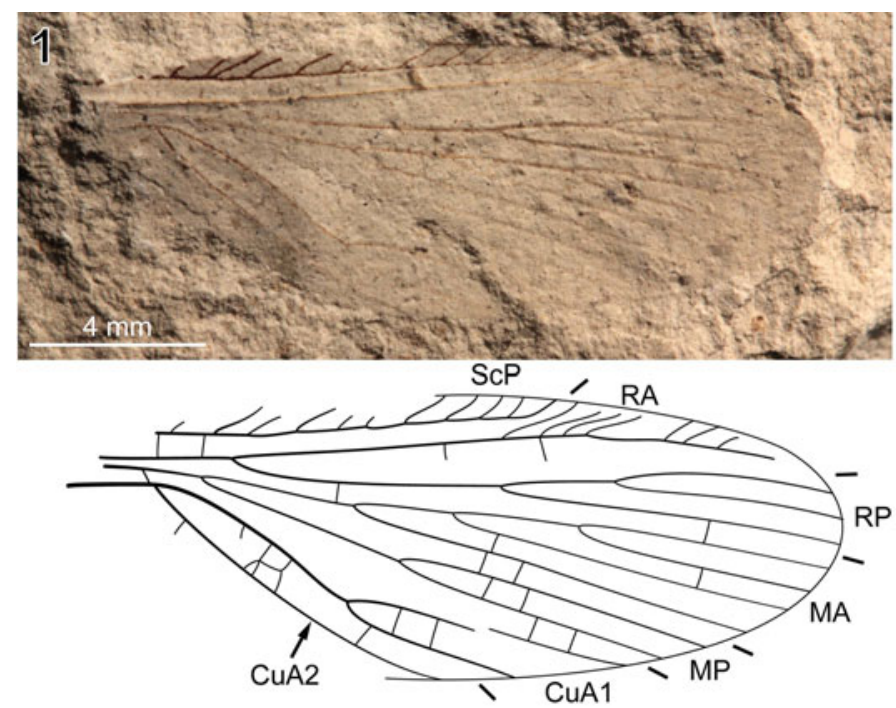
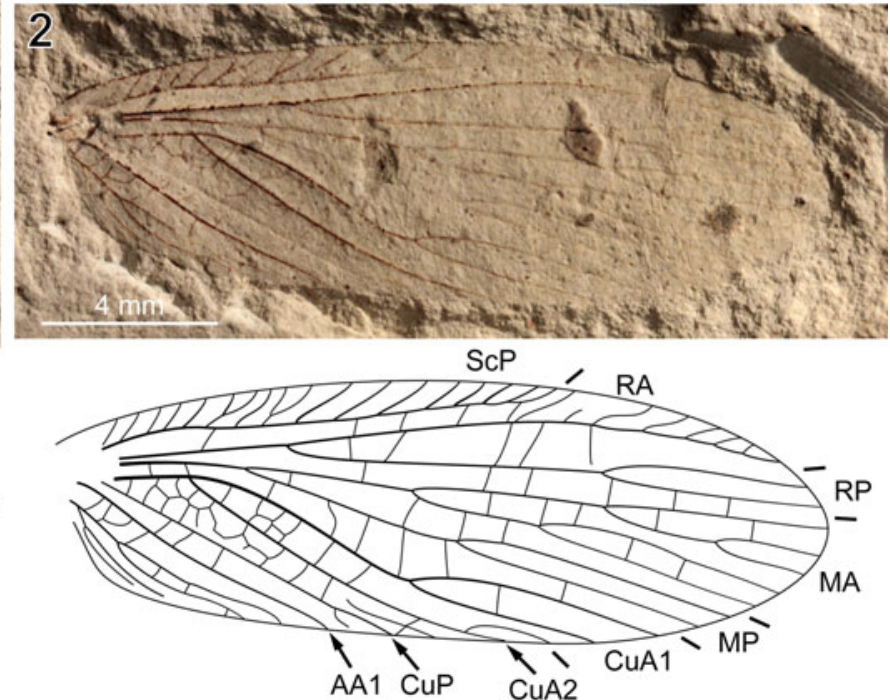

Figure 12. Liomopterum sellardsi Carpenter, 1950: (1) MCZ 4935, paratype, left forewing, photograph (positive imprint, flipped horizontally, eth.-dry composite) and reconstruction; (2) MCZ 4978, holotype, left forewing, photograph (positive imprint, flipped horizontally) and reconstruction. Abbreviations as in Figure 8.

RP with three branches $(2,1)$, with first fork very distal; crossveins mostly scalariform, occasionally sigmoidal, reticulated in area between MP and $\mathrm{CuA} 1$; membrane hyaline.

Etymology.-The specific epithet refers to Sperbersbach, the locality from which the holotype was recovered.

Material.-Holotype only.

Remarks.-Assignment of the new material to the speciose genus Liomopterites is based on $\mathrm{CuA} 1$ and $\mathrm{CuA} 2$ remaining close to each other and subparallel. Also, in most species currently assigned to this genus, crossveins in the area

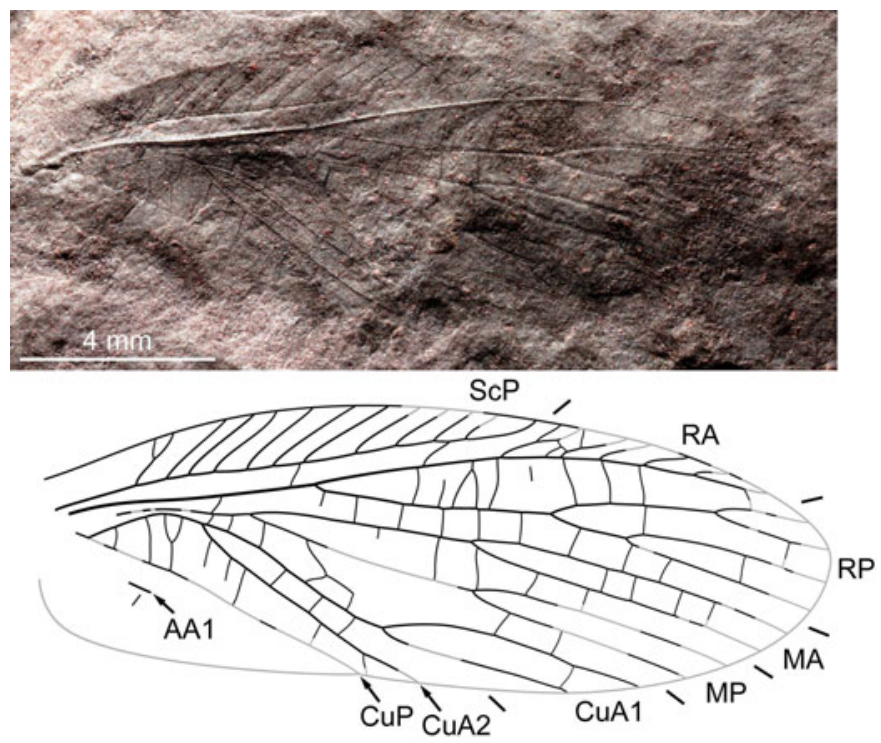

Figure 13. Uralioma thuringiensis $\mathrm{n}$. sp.: NHMS-WP 5850, holotype, right forewing, photograph (positive imprint, eth.-eth.-dry composite) and reconstruction. Abbreviations as in Figure 8. between RA and RP are scalariform (i.e., not reticulated) as in the new material (and unlike, e.g., in Liomopterella Sharov, 1961). In its venation features (i.e., number of branches, location of forks), the new material is almost identical to Liomopterites pomorus Storozhenko, 1992 (Soyana, Russian Federation; early Permian). However, the forewing of this species is almost twice as large as in the new material, and has denser crossvenation. Liomopterites expletus Sharov, 1961 (Kuznetsk, Russian Federation; early Permian) also shares a very similar venation branching pattern to that of the new material, but this species displays two rows of cells in the area between RA and RP (versus a single row in the new material)
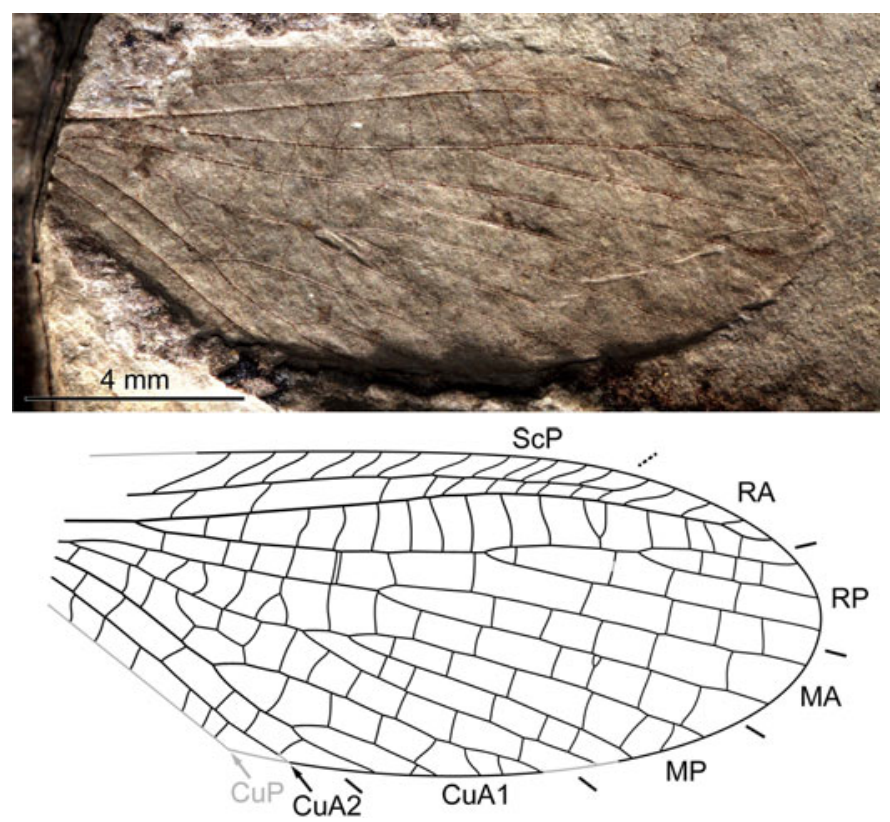

Figure 14. Liomopterites sperbersbachensis n. sp., NHMS-Am 3212, holotype, right forewing, photograph (negative imprint, light-mirrored, flipped horizontally, eth.-dry composite) and reconstruction. Abbreviations as in Figure 8. 

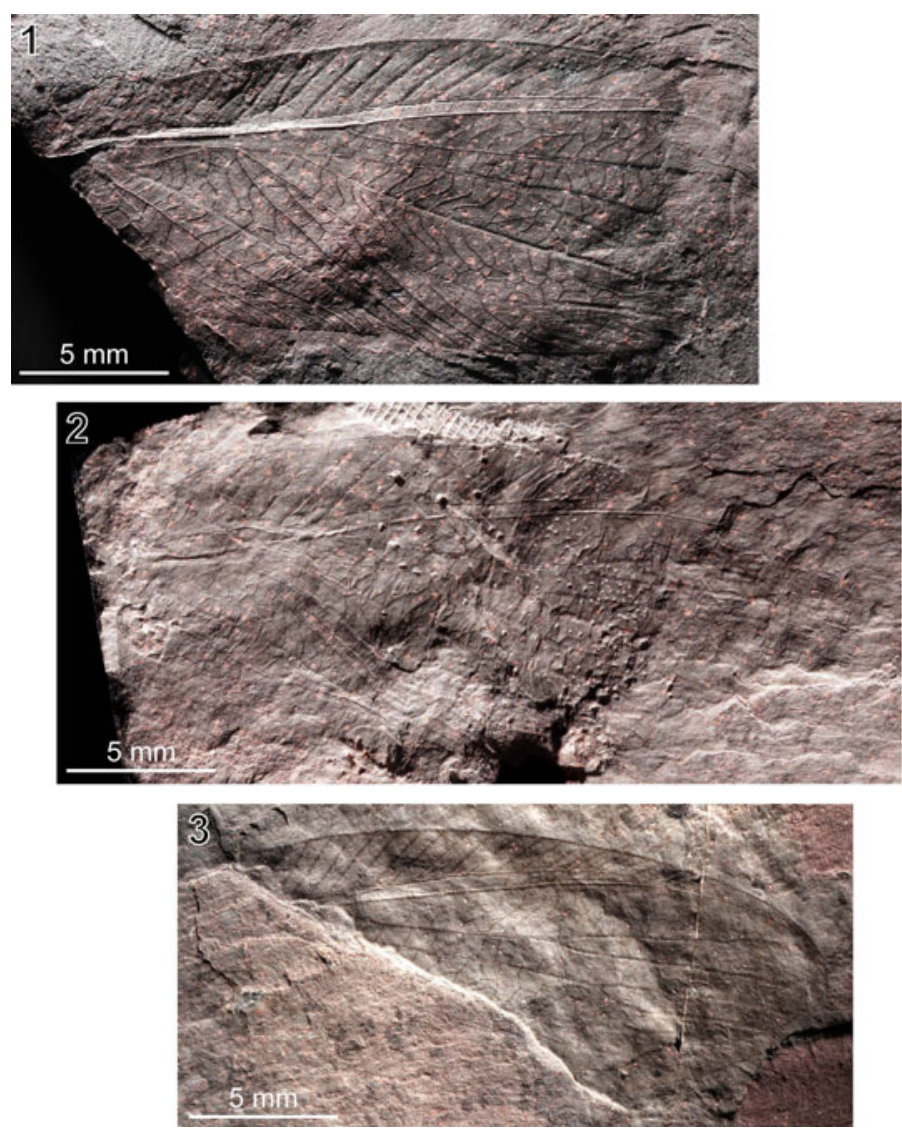
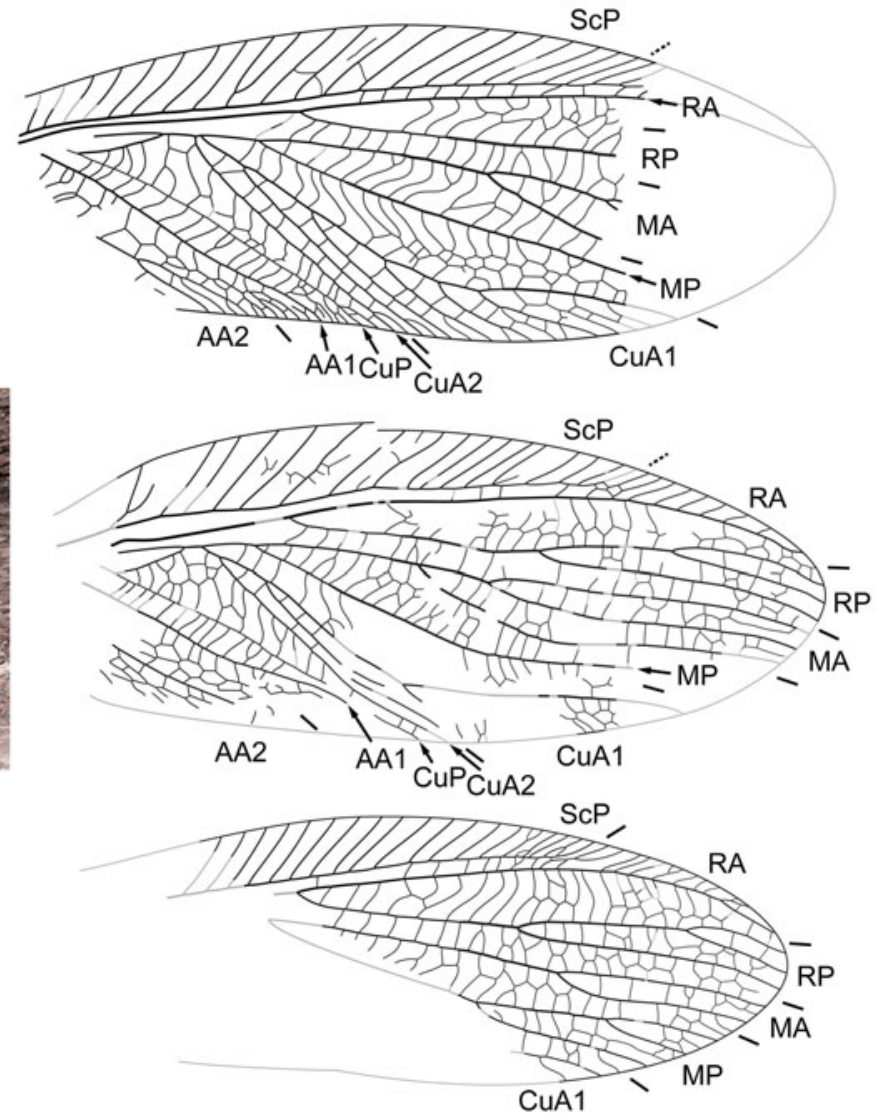

Figure 15. Cabarzopterum magnificus n. gen. n. sp.: (1) NHMS-WP 5127, holotype, right forewing, photograph (positive imprint, eth.-eth.-dry composite) and reconstruction; (2) NHMS-WP 5696, left forewing, photograph (negative imprint, light-mirrored, eth.-dry composite) and reconstruction; (3) NHMS-WP 7831, right forewing, photograph (negative imprint, flipped horizontally, light-mirrored, eth.-dry composite) and reconstruction. Abbreviations as in Figure 8.

and is much larger (forewing 23.5-24.5 mm long versus $\sim 16.4$ $\mathrm{mm}$ ). The new material does not easily compare with any further species currently assigned to Liomopterites, in particular regarding its size (small species commonly have many fewer branches). It is therefore assigned to a new species.

\section{Family undetermined}

Genus Cabarzopterum new genus

Type species.-Cabarzopterum magnificus n. gen. n. sp., from Cabarz, Germany; early Permian; monotypic.

Diagnosis.-As for the type species, as a consequence of monotypy.

Occurrence.-Cabarz, Germany; Goldlauter Formation, early Permian.

Etymology.-Derived from Cabarz, the locality from which the type species was recovered, plus ptera: Gr. wing.

Remarks.-The type species of this genus (Fig. 15) displays a combination of traits themselves known over distinct families. Notably, the occurrence of vein thickenings and of an anteriormost branch of $\mathrm{CuA} 1$ almost parallel to the posterior wing margin (for some distance) are known to occur in
Epideigmatidae Handlirsch, 1911 (see Béthoux et al., 2005; Béthoux, 2007; Aristov, 2011) and in Phenopterum elongatum Sellards, 1909 (see Béthoux and Nel, 2010), regarded as a member of Sylvaphlebiidae Martynov, 1940. However, none of the corresponding species displays a CuA1 with so many branches, e.g., early position of the first fork of $\mathrm{CuA} 1$, and a rather long fusion of $\mathrm{M}$ and $\mathrm{CuA}$ (or, even, continued with $\mathrm{CuA} 1$ ). The strongly sigmoidal crossveins are also unusual compared with known Epideigmatidae. Conversely, $\mathrm{M}$ and $\mathrm{CuA}$ fuse for some distance in Euryptilonidae, but the corresponding species lack vein thickenings. A very early fork of CuA1 is known in some species of Permulidae Aristov and Storozhenko, 2011, including Permula lebachensis (Schlechtendal, 1912) (Fig. 16; Odernheim Lake horizon M10, Germany, Odernheim Subformation, Meisenheim Formation, early Permian), but only in species in which $\mathrm{M}$ and $\mathrm{CuA}$ are distinct (those having fused $\mathrm{M}$ and $\mathrm{CuA}$ have a distal first fork of $\mathrm{CuA} 1$ ). Permulidae species are not known to possess vein thickenings. In summary, considering the singularity of the new material, we propose to assign it to a new species and genus, but refrain from proposing positive familial assignment.

Cabarzopterum magnificus new species Figure 15 
Holotype.-NHMS-WP 5127, from Cabarz, Germany; early Permian.

Diagnosis.-Forewing: area between anterior wing margin and $\mathrm{ScP}$ distinctly broader than that between $\mathrm{ScP}$ and RA; ScP veinlets numerous, denser toward apex, with few (or inconspicuous) crossveins between them; RP, MA, and MP branched, with seven or eight branches; $\mathrm{CuA}$ fused with $\mathrm{M}$ for some distance; first fork of $\mathrm{CuA} 1$ very early; $\mathrm{CuA} 1$ strongly bent, posteriorly pectinate, with numerous branches, with anteriormost (terminal) one almost parallel to posterior wing margin; $\mathrm{CuA} 1$ reaching posterior wing margin opposite fourth fifth of wing length; in distal half, occurrence of thickenings along RP, MA, MP, their branches, and anteriormost branch of $\mathrm{CuA1}$, altering their elevation as strongly concave; crossveins mostly sigmoidal (scalariform between $\mathrm{CuA}$ branches), reticulated.

Occurrence.-Cabarz, Germany; Goldlauter Formation, early Permian.

Description.-Forewing: $\sim 23.4-27.9 \mathrm{~mm}$ long, $\sim 9.0-10.6$ $\mathrm{mm}$ wide; RP with three branches $(2,1)$; MA with two or three branches; MP with three branches, possibly simple or with distal fork; fusion of $\mathrm{M}+\mathrm{CuA} / \mathrm{CuA} 10.6-1.3 \mathrm{~mm}$ long; $\mathrm{CuA}$ forked into $\mathrm{CuA} 1$ and $\mathrm{CuA} 2$ although fused with $\mathrm{M}$ or shortly after the point of divergence of $\mathrm{M}$ and $\mathrm{CuA} ; \mathrm{CuA} 2$ simple, slightly bent; CuP simple, weak; AA1 simple, strong; area between AA1 and anterior branch of AA2 broad; dense, thick veinlets occurring along posterior wing margin in areas between $\mathrm{CuA} 2$ and AA veins; venation dark, membrane hyaline.

Etymology.—magnificus: L., splendid; referring to the esthetic qualities of the forewing venation in this species.

Materials.-NHMS-WP 5127, holotype (Fig. 15.1), 5696 (Fig. 15.2), and 7831 (Fig. 15.3), all from Cabarz, Germany (early Permian).

Specimen descriptions.-NHMS-WP 5127 (Fig. 15.1): positive and negative imprints of very well-preserved right forewing, distal fifth missing; $21.0 \mathrm{~mm}$ long as preserved $(\sim 27.9 \mathrm{~mm}$ long if complete), $10.4 \mathrm{~mm}$ wide; as preserved, RP simple (if branched, at best distal to its midlength), MA with three branches $(2,1)$, MP simple (if branched, at best very distally); fusion of $\mathrm{M}+\mathrm{CuA}$ continued into $\mathrm{M}+\mathrm{CuA} 1$ fusion (total fusion $1.3 \mathrm{~mm}$ long); CuA1 with six well-formed branches.

NHMS-WP 5696 (Fig. 15.2): positive and negative imprints of moderately well-preserved left forewing, creased and disrupted in several areas, with posterior margin and base partly missing; $23.4 \mathrm{~mm}$ long as preserved $(\sim 26.9 \mathrm{~mm}$ if complete), $\sim 10.6 \mathrm{~mm}$ wide; MA with three branches $(2,1)$, posterior branch of MA slightly sigmoidal; MP simple (if branched, at best very distally), bent downward; $\mathrm{CuA}$ fused with $\mathrm{M}$ for $0.6 \mathrm{~mm}$, forked into $\mathrm{CuA} 1$ and $\mathrm{CuA} 2$ shortly after its divergence from $\mathrm{M}$; $\mathrm{CuA} 1$ with four visible branches, very close to each other; AA1 partly overlapping $\mathrm{CuP}$, probably as consequence of crease or wing disruption.
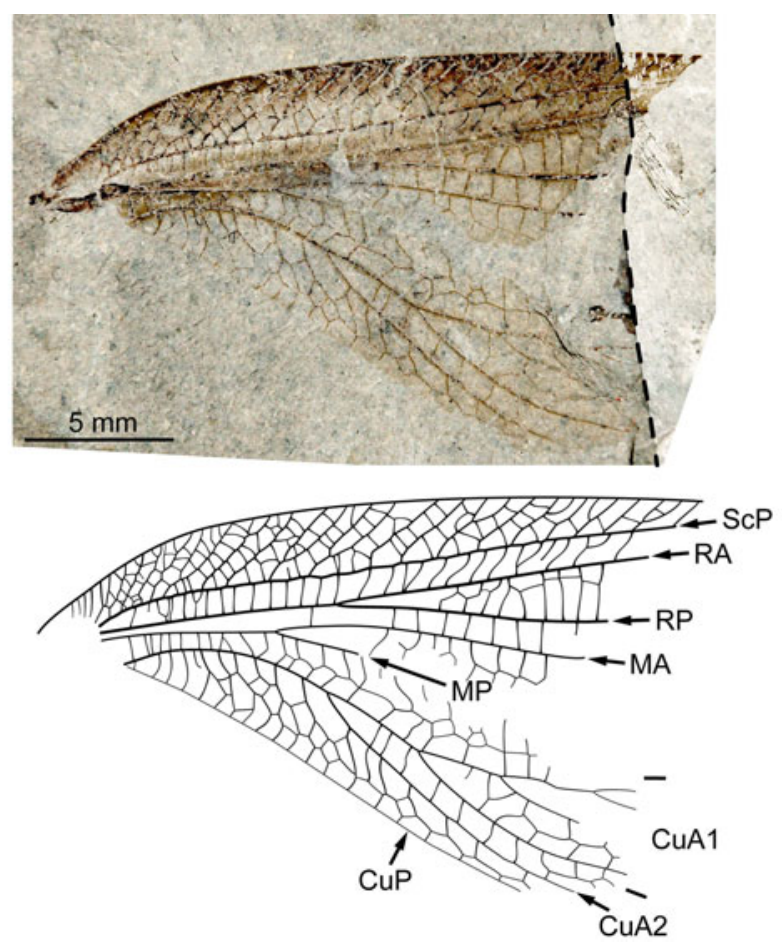

Figure 16. Permula lebachensis (Schlechtendal, 1912), IGPB-Guthörl-28 holotype, right forewing, photograph (dry-dry composite; the dotted line indicates the edge of one of the imprints) and reconstruction. Abbreviations as in Figure 8 .

NHMS-WP 7831 (Fig. 15.3): negative imprint of wellpreserved right forewing, with most of posterobasal area missing; $19.3 \mathrm{~mm}$ long as preserved ( $23.4 \mathrm{~mm}$ if complete), $\sim 9.0 \mathrm{~mm}$ wide if complete; MA with two branches, fork located distally; MP with three branches $(2,1)$.

Remarks.-Some variations in venation pattern and size were observed among the specimens, but they all share very peculiar features, suggesting that they all belong to the same species.

\section{Discussion}

The grylloblattidan faunas of Sperbersbach and Cabarz are essentially similar, with Pictoborella clara n. gen. n. sp. common in both outcrops, followed by Liomopterum fuscatum $\mathrm{n}$. sp. The species Uralioma thuringiensis $\mathrm{n}$. sp. and Liomopterites sperbersbachensis $\mathrm{n}$. sp., of similar size, are both rare. A contrasting feature between the two localities is the occurrence of the large species Cabarzopterum magnificus n. gen. n. sp. at Cabarz only. This difference can probably be accounted for by differences in the depositional environment and local paleoclimate. The Sperbersbach entomofauna is preserved in a $\sim 4.50 \mathrm{~m}$ thick laminated black shale succession of a perennial, fish-dominated lake. Lamination is governed by a strongly seasonal climate and indicates the occurrence of a lake that lasted for several thousand years (Roscher and Schneider, 2006). The associated flora is dominated by hygrophilous (mainly Psaronius tree ferns) to mesophilous elements (Barthel and Brauner, 2015). This setting is identical to the Odernheim Lake black shales of the Saar-Nahe 
Basin, from which the holotype of Pictoborella germanica was recovered. In contrast, the Cabarz entomofauna was sampled from dm-thick laminated black shales deposited in shallow temporary lakes, typically dominated by branchiosaurid amphibians, and located in a lake-and-pond landscape (Werneburg, 2002). Consistent with a reconstruction of short-living lakes and ponds subjected to strongly seasonal climate, the associated flora is sparse and dominated by mesophilous to xerophilous elements (Barthel and Brauner, 2015).

Future descriptions of representatives of other insect orders recovered at Sperbersbach and Cabarz will complement the current account and our knowledge of Eurasian Permian insect assemblages. It can already be assessed that Sperbersbach entomofauna is overly dominated by stem relatives of Dictyoptera (cockroaches and mantises). In contrast, the Cabarz entomofauna is more diversified. Notably, as noted above for grylloblattidans, it includes larger insects, e.g., representatives of the extinct Rostropalaeoptera and stem relatives of Orthoptera (grasshoppers and crickets), remaining to be described. Considering these diversity features and ecological preferences of the associated flora, Cabarz (early Asselian) appears to be very similar to the famous but younger (Sakmarian/Artinskian) Obora locality (Czech Republic), representing pond deposits.

\section{Acknowledgments}

We are grateful to two anonymous reviewers and S. Storozhenko for useful comments on a previous version of the current account, and to the editorial board of Journal of Paleontology for managing the submission process and for relevant comments. We thank R. Werneburg and A. Amelang (Naturhistorisches Museum Schloss Bertholdsburg) for organizing excavations and providing specimens from the Sperbersbach and Cabarz excavation sites. We are grateful to C. Brauckmann and G. Heumann (Bonn University) for providing data and photographs of various specimens. We are grateful to the Museum of Comparative Zoology and Harvard University for allowing the reproduction of copyrighted material. We are grateful to the administration of the Cabarz quarry for allowing fossil sampling. The first author thanks the Ernst Mayr Travel Grant for financial support during her research visit to the F.M. Carpenter collection (February-March 2012) at the Museum of Comparative Zoology, and the German Academic Exchange Service (DAAD) for financial support during her stay in Germany, April 2013 to April 2014, during which time the core data for this research was collected and prepared. JWS thanks the German Research Foundation (DFG) for support by the grant DFG-Schn 408/22 and Kazan Federal University, Russia, for support in the framework of the state assignment no. 5.2192.2017/4.6. The senior author thanks the Alexander von Humboldt Foundation for financial support for a visit at Freiberg in 2013. This research was supported by the National Natural Science Foundation of China (No. 31900342).

\section{Data availability statement}

Data available from the Dryad Digital Repository: https://doi. org/10.5061/dryad.02v6wwq2v

\section{References}

Aristov, D.S., 2004, The fauna of grylloblattid insects (Grylloblattida) of the lower Permian locality of Tshekarda: Paleontological Journal, v. 38, p. $80-145$.

Aristov, D.S., 2011, Revision of the family Epideigmatidae (Insecta: Grylloblattida): Paleontological Journal, v. 45, p. 397-405, https://doi.org/10.1134/ S0031030111040034.

Aristov, D.S., and Storozhenko, S.Y., 2011, Review of the Permian family Permulidae nomen novum pro Aliculidae Storozhenko, 1997 (Grylloblattida): ZooKeys, v. 130, p. 111-130, https://doi.org/10.3897/zookeys.130.1489.

Aristov, D.S., Bashkuev, A., Golubev, V.K., Gorochov, A.V., Karasev, E.V., Kopylov, D.S., Ponomarenko, A.B., Rasnitsyn, A.P., Rasnitsyn, D.A., Sinitshenkova, N.D., Sukatsheva, I.D., and Vassilenko, D.V., 2013, Fossil insects of the middle and upper Permian of European Russia: Paleontological Journal, v. 47, p. 641-832, https://doi.org/10.1134/S0031030113070010.

Barthel, M., and Brauner, S., 2015, Die Rotliegendflora des Thüringer Waldes, Supplementum: Semana, v. 30, p. 3-37.

Beckemeyer, R.J., and Hall, J.D., 2007, The entomofauna of the lower Permian fossil insect beds of Kansas and Oklahoma, USA: African Invertebrates, v. 48, p. 23-39.

Béthoux, O., 2007, Emptying the Paleozoic wastebasket for insects: Members of a Carboniferous 'protorthopterous family' reassigned to natural groups: Alavesia, v. 1, p. 41-48.

Béthoux, O., and Nel, A., 2010, Description of a new grylloblattidan insect from Montceau-les-Mines (Pennsylvanian; France) and definition of Phenopterum Carpenter, 1950: Systematic Entomology, v. 35, p. 546-553, https://doi.org/10.1111/j.1365-3113.2010.00527.x.

Béthoux, O., Nel, A., Lapeyrie, J., and Gand, G., 2005, New data on Paleozoic 'grylloblattid' insects (Neoptera): Journal of Paleontology, v. 79, p. 125-138, 629630, https://doi.org/10.1666/0022-3360(2005)079<0125:NDOPGI $>2.0 . C O ; 2$.

Brannoch, S.K., Wieland, F., Rivera, J., Klass, K.-D., Béthoux, O., and Svenson, G.J., 2017, Manual of praying mantis morphology, nomenclature, and practices (Insecta, Mantodea): Zookeys, v. 696, p. 1-100, https://doi.org/10. 3897/zookeys.696.12542.

Brauckmann, C., and Willmann, R., 1990, Insekten aus dem Permo-Silesium der Bohrung Weiterstadt 1 (Blattodea, 'Protorthoptera'; Oberrheinische Tiefebene, SW-Deutschland): Neues Jahrbuch für Geologie und Paläontologie, v. 1807 , p. $470-478$.

Carpenter, F.M., 1935, The lower Permian of Kansas, part 7: The order Protoperlaria: Proceedings of the American Academy of Arts and Sciences, v. 70, p. 103-146, https://doi.org/10.2307/20023126.

Carpenter, F.M., 1950, The lower Permian insects of Kansas, part 10: The order Protorthoptera: The family Liomopteridae and its relatives: Proceedings of the American Academy of Arts and Sciences, v. 78, p. 185-219, https:// doi.org/10.2307/20023577.

Carpenter, F.M., 1992, Superclass Hexapoda, in Kaesler, R.L., ed., Treatise on Invertebrate Paleontology, Part R, Arthropoda 4, Volume 3: Boulder, Colorado, and Lawrence, Kansas, Geological Society of America (and University of Kansas Press), 277 p.

Cohen, K.M., Finney, S.C., Gibbard, P.L., and Fan, J.-X., 2020, The ICS International Chronostratigraphic Chart (2013, updated): Episodes, v. 36, p. 199-204, https://doi.org/10.18814/epiiugs/2013/v36i3/002.

Evangelista, D.A., Wipfler, B., Béthoux, O., Donath, A., Fujita, M., Kohli, M.K., Legendre, F., Liu, S., Machida, R., Misof, B., Peters, R.S., Podsiadlowski, L., Rust, J., Schuette, K., Tollenaar, W., Ware, J.L., Wappler, T., Zhou, X., Meusemann, K., and Simon, S., 2019, An integrative phylogenomic approach illuminates the evolutionary history of cockroaches and termites (Blattodea): Proceedings of the Royal Society, London, ser. B, v. 286, p. 20182076, http:// doi.org/10.1098/rspb.2018.2076.

Handlirsch, A., 1906, Revision of American Paleozoic insects: Proceedings of the United States National Museum, v. 29, p. 661-820.

Handlirsch, A., 1911, New Paleozoic insects from the vicinity of Mazon Creek, Illinois: American Journal of Science, ser. 4, v. 31, p. 297-326, 353-377.

Kukalová, J., 1964, Permian insects of Moravia, part 2: Liomopteridea: Sbornik Geologickych Ved, Paleontologie, v. 3, p. 39-118.

Linnaeus, C., 1758, Systema Naturae per Regna Tria Naturae (tenth edition), Volume 1, Regnum Animale: Stockholm, Laurentii Salvii, 824 p.

Martynov, A.V., 1940, [Permian fossil Insects from Tshekarda]: Trudy Paleontologicheskogo Instituta, Akademiya Nauk SSSR, v. 11, p. 5-62. [in Russian with extended English summary]

Montagna, M., Tong, K.J., Magoga, G., Strada, L., Tintori, A., Ho, S.Y.W., and Lo, N., 2019, Recalibration of the insect evolutionary time scale using Monte San Giorgio fossils suggests survival of key lineages through the endPermian extinction: Proceedings of the Royal Society B, Biological Sciences, v. 286, p. 1-9, https://doi.org/10.1098/rspb.2019.1854.

Poschmann, M., and Nel, A., 2020, New early Permian insects (Insecta: Paoliida and Grylloblattida) from the Niedermoschel black shale of the Saar-Nahe 
Basin, SW Germany: Palaeoentomology, v. 3, p. 623-631, https://doi.org/ 10.11646/palaeoentomology.3.6.14.

Prokop, J., Weiss, K.-D., Dechambre, R.-P., and Nel, A., 2012, Early Permian insects from Saar-Nahe Basin of Odernheim town site, Rheinland-Pfalz in Germany (Insecta, Grylloblattida, Blattinopseida): Geodiversitas, v. 34 p. 271-281, https://doi.org/10.5252/g2012n2a2.

Rasnitsyn, A.P., 1976, [Grylloblattidy-Sovremennye predstaviteli otryada Protoblattod (Insecta, Protoblattodea)]: Doklady Akademii Nauk SSSR, v. 228, p. 502-504. [in Russian]

Roscher, M., and Schneider, J.W., 2006, Permo-Carboniferous climate: Early Pennsylvanian to late Permian climate development of central Europe in a regional and global context, in Lucas, S.G., Cassinis, G., and Schneider, J.W., eds., Non-Marine Permian Biostratigraphy and Biochronology: London, Geological Society, Special Publications 265, p. 95-136.

Schlechtendal, D., 1912, Untersuchung über die karbonischen Insekten und Spinnen von Wettin: Nova Acta Abhandlungen der Kaiserlichen LeopoldinischCarolinischen Deutschen Akademie der Naturforscher, v. 98, p. 1-186.

Schneider, J.W., 1982, Entwurf einer biostratigraphischen zonengliederung mittels der Spiloblattinidae (Blattodea, Insecta) für das kontinentale euramerischa Permokarbon: Freiberger Forschungshefte, ser. C, v. 375, p. $27-47$.

Schneider, J.W., and Werneburg, R., 1993, Neue Spiloblattinidae (Insecta, Blattodea) aus dem Oberkarbon und Unterperm von Mitteleuropa sowie die Biostratigraphie des Rotliegend: Veröffentlichungen des Naturhistorischen Museums Schleusingen, v. 1993, p. 31-52.

Schneider, J.W., Lucas, S.G., Scholze, F., Voigt, S., Marchetti, L., Klein, H., Opluštil, S., Werneburg, R., Golubev, V.K., Barrick, J.E., Nemyrovska, T., Ronchi, A., Day, M.O., Silantiev, V.V., Rössler, R., Saber, H., Linnemann, U., Zharinova, V., and Shen, S.-Z., 2020, Late Paleozoic-early Mesozoic continental biostratigraphy-Links to the Standard Global Chronostratigraphic Scale: Palaeoworld, v. 29, p. 186-238, https://doi.org/ 10.1016/j.palwor.2019.09.001.

Sellards, E.H., 1909, Types of Permian insects, part 3: Megasecoptera, Oryctoblattinidae and Protorthoptera: American Journal of Science, ser. 4, v. 27, p. $151-173$.

Sharov, A.G., 1961, [Otryad Paraplecoptera (order Paraplecoptera)], in Rohdendorf, B.B., Becker-Migdisova, E.E., Martynova, O.M., and Sharov, A.G.,
[Paleozoyskie Nasekomye Kuznetskogo Basseyna]: Trudy Paleontologicheskogo Instituta, Akademiya Nauk SSSR, v. 85, p. 164-224. [in Russian]

Storozhenko, S.Y., 1992, Permian fossil insects of north-east Europe: New Liomopterids: Deutsche Entomologische Zeitschrift, (N.F.), v. 39, p. 1-3

Storozhenko, S.Y., 1998, [Sistematika, Filogeniya i Evolyutsiya Grilloblattidovykh Nasekomykh (Insecta: Grylloblattida)]: Vladivostok, Dal'nauka, 207 p. [in Russian]

Storozhenko, S.Y., 2002, Order Grylloblattida Walker, 1914 (= Notoptera, Crampton, 1915, = Grylloblattodea Brues et Melander, 1932, + Protorthoptera Handlirsch, 1906, = Paraplecoptera Martynov, 1925, + Protoperlaria Tillyard, 1928), in Rasnitsyn, A.P., and Quicke, D.L.J., eds., History of Insects: Dordrecht, The Netherlands, Kluwer Academic Publishers, p. 278-281.

Storozhenko, S.Y., and Aristov, D.S., 1999, New genus of the family Liomopteridae (Insecta: Grylloblattida) from lower Permian of Russia: Far Eastern Entomologist, v. 76, p. 6-8.

Walker, E.M., 1914, On new species of Orthoptera, forming a new genus and family: Canadian Entomologist, v. 46, p. 93-99.

Werneburg, R., 2002, Apateon dracyiensis-eine frühe Pionierform der Branchiosaurier aus dem Europäischen Rotliegend, Teil 2: Paläoökologie: Veröffentlichungen des Naturhistorischen Museums Schleusingen, v. 17, p. 17-32.

Wipfler, B., Bai, M., Schoville, S., Dallai, R., Uchifune, T., Machida, R., Cui, Y., and Beutel, R.G., 2014, Ice crawlers (Grylloblattodea)-The history of the investigation of a highly unusual group of insects: Journal of Insect Biodiversity, v. 2, p. 1-25, https://doi.org/10.12976/jib/2014.2.2.

Wipfler, B., Letsch, H., Frandsen, P.B., Kapli, P., Mayer, C., Bartel, D., Buckley, T.R., Donath, A., Edgerly-Rooks, J.S., Fujita, M., Liu, S., Machida, R. Mashimo, Y., Misof, B., Niehuis, O., Peters, R.S., Petersen, M., Podsiadlowski, L., Schütte, K., Shimizu, S., Uchifune, T., Wilbrandt, J., Yan, E., Zhou, X., and Simon, S., 2019, Evolutionary history of Polyneoptera and its implications for our understanding of early winged insects: Proceedings of the National Academy of Sciences of the United States of America, v. 116, p. 3024-3029, https://doi.org/10.1073/pnas.1817794116.

Accepted: 26 September 2021 